\title{
Resistance mechanisms of Cryptococcus spp. and plant compounds as tools to combat
}

\section{them}

Mecanismos de resistência de Cryptococcus spp. e compostos de plantas como ferramentas para combatê-los

Mecanismos de resistencia de Cryptococcus spp. y compuestos vegetales como herramientas para combatirlos

\author{
Suéllen Pedrosa da Silva \\ ORCID: https://orcid.org/0000-0001-5142-6210 \\ Federal University of Pernambuco, Brazil \\ E-mail: suellenpedrosasilva@gmail.com \\ Clarice Barbosa Lucena da Costa \\ ORCID: https://orcid.org/0000-0002-1846-5389 \\ Federal University of Pernambuco, Brazil \\ E-mail: clarice.lucena01@gmail.com \\ José Dayvid Ferreira da Silva \\ ORCID: https://orcid.org/0000-0001-6274-7968 \\ Federal University of Pernambuco, Brazil \\ E-mail: dayvid.silva12@gmail.com \\ Robson Raion de Vasconcelos Alves \\ ORCID: https://orcid.org/0000-0002-7539-0491 \\ Federal University of Pernambuco, Brazil \\ E-mail: robson.raion@gmail.com \\ Guilherme Antonio de Souza Silva \\ ORCID: https://orcid.org/0000-0003-4364-6648 \\ Federal University of Pernambuco, Brazil \\ E-mail: guilherme.assufpe@gmail.com \\ Anderson Felipe Soares de Freitas \\ ORCID: https://orcid.org/0000-0001-7444-8957 \\ Federal University of Pernambuco, Brazil \\ E-mail: afbiomedicine@gmail.com \\ Caio César da Silva Guedes \\ ORCID: https://orcid.org/0000-0003-0057-9326 \\ Federal University of Pernambuco, Brazil \\ E-mail: caio.cs.guedes@gmail.com \\ Amanda de Oliveira Marinho \\ ORCID: https://orcid.org/0000-0001-7486-6868 \\ Federal University of Pernambuco, Brazil \\ E-mail: amandamarinho208@gmail.com \\ Patrícia Maria Guedes Paiva \\ ORCID: https://orcid.org/0000-0003-3467-708X \\ Federal University of Pernambuco, Brazil \\ E-mail: patrícia.paiva@ufpe.br \\ Thiago Henrique Napoleão \\ ORCID: https://orcid.org/0000-0002-0065-2602 \\ Federal University of Pernambuco, Brazil \\ E-mail: thiago.napoleao@ufpe.br
}

\begin{abstract}
Cryptococcus is a genus of dimorphic basidiomycete fungi found in the form of yeasts and filaments. Cryptococcosis has as main etiological agents the species Cryptococcus neoformans and Cryptococcus gattii. This disease is considered a public health problem and has becoming more alarming because of the limitations of antimicrobials available to its treatment, in addition to an increase in reports of fungal resistance. In this sense, the present review sought to survey information on the resistance mechanisms of Cryptococcus spp. against the main drugs used in cryptococcosis therapy as well as on the antimicrobial activities of plants against these fungi. Studies have reported that several mechanisms
\end{abstract}


may be involved in fungal resistance to drugs including drug inactivation by enzymes, expression of efflux pumps and others drug transporters, as well as changes in the drug target and/or implementation of alternative metabolic pathways. As an alternative to conventional antimicrobials, substances and molecules extracted from plants have demonstrated potential for controlling these pathogens. These phytochemicals can trigger the inhibition and/or death of Cryptococcus through morphological changes on fungi cells, inhibition of ergosterol synthesis, cell leakage, capsular decrease, interference in cell division, reduction of activity of several enzymes such as laccase and urease, inhibition of biofilm formation, among others. In this sense, plants are an important source of bioactive compounds with antimicrobial activity that can be studied in the search for new drugs that are increasingly effective, specific and less toxic in the control of cryptococcosis.

Keywords: Antimicrobial extracts; Resistance of Cryptococcus spp.; Toxicity of antimicrobial drugs; Mechanism of action of antimicrobial plants.

\section{Resumo}

Cryptococcus é um gênero de fungos basidiomicetos dimórficos encontrados na forma de leveduras e filamentos. A criptococose tem como principais agente etiológicos as espécies Cryptococcus neoformans e Cryptococcus gattii. Essa doença é considerada um problema de saúde pública e tem se tornado mais alarmante devido às limitações dos antimicrobianos disponíveis para o seu tratamento, além do aumento nos relatos de resistência microbiana. Nesse sentido, a presente revisão buscou levantar informações sobre dos mecanismos de resistência de Cryptococcus spp. frente aos principais fármacos utilizados no tratamento da criptococose, bem como sobre as atividades antimicrobianas de plantas contra esses fungos. Estudos reportam que diversos mecanismos podem estar envolvidos na resistência fúngica a fármacos antimicrobianos, incluindo a inativação de drogas por enzimas, expressão de bombas de efluxo, alterações no alvo da droga e/ou implementação de vias metabólicas alternativas. Como alternativa aos antimicrobianos convencionais, substâncias e moléculas extraídas de plantas têm se mostrado potencial para o controle desses patógenos. Esses fitoquímicos podem desencadear a inibição e/ou morte de microrganismos de Cryptococcus através de: alterações morfológicas nas células fúngicas, extravasamento celular, diminuição capsular, interferência na divisão celular, redução da atividade de várias enzimas como lacase e urease, inibição da formação de biofilme, entre outros. Nesse sentido, as plantas são importantes fontes de compostos bioativos com atividade antimicrobiana que podem ser estudadas na busca de novos fármacos cada vez mais eficazes, específicos e menos tóxicos no controle da criptococose. Palavras-chave: Extratos antimicrobianos; Resistência de Cryptococcus spp.; Toxicidade de antimicrobianos, Mecanismo de ação de plantas antimicrobianas.

\section{Resumen}

Cryptococcus es un género de hongos basidiomicetos dimórficos que se encuentran en forma de levaduras y filamentos. La criptococosis tiene como principales agentes etiológicos las especies Cryptococcus neoformans y Cryptococcus gattii. Esta enfermedad es considerada un problema de salud pública y se ha vuelto más alarmante debido a las limitaciones de los antimicrobianos disponibles para su tratamiento, además del aumento de reportes de resistencia microbiana. En este sentido, la presente revisión buscó generar información sobre los mecanismos de resistencia de Cryptococcus spp. contra los principales fármacos utilizados en el tratamiento de la criptococosis, así como sobre las actividades antimicrobianas de las plantas contra estos hongos. Los estudios informan que varios mecanismos pueden estar involucrados en la resistencia de los hongos a los medicamentos antimicrobianos, incluida la inactivación de los medicamentos por las enzimas, la expresión de bombas de eflujo, los cambios en el objetivo del medicamento y/o la implementación de vías metabólicas alternativas. Como alternativa a los antimicrobianos convencionales, las sustancias y moléculas extraídas de plantas han demostrado tener potencial para el control de estos patógenos. Estos fitoquímicos pueden desencadenar la inhibición y/o muerte de los microorganismos del género Cryptococcus a través de: cambios morfológicos en las células fúngicas, extravasación celular, disminución capsular, interferencia en la división celular, reducción de la actividad de diversas enzimas como la lacasa.y ureasa, inhibición de la formación de biofilmes, entre otros. En este sentido, las plantas son fuentes importantes de compuestos bioactivos con actividad antimicrobiana que pueden ser estudiados en la búsqueda de nuevos fármacos cada vez más efectivos, específicos y menos tóxicos en el control de la criptococosis.

Palabras clave: Extractos antimicrobianos; Resistencia de Cryptococcus spp.; Toxicidad antimicrobiana; Mecanismo de acción de plantas antimicrobianas.

\section{Introduction}

Cryotococcus is a genus of dimorphic basidiomycete fungi found in the form of yeasts and filaments. They are ubiquitous in the environment being potential opportunistic pathogens responsible for causing cryptococcal meningitis, which can be a fatal disease if untreated (Springer et al., 2017; Zhao et al., 2019). Cryptococcus spp. have a facility to adapt quickly to various conditions, which favors their survival in the environment and in infection sites. The two main pathogenic groups are 
the complexes $C$. gatti, most reported species in infections to immunocompetent individuals, and $C$. neoformans, which predominantly infect immunocompromised patients (Alspaugh 2015; Hagen et al., 2017; Watkins et al., 2017).

C. gattii and C. neoformans can be found in different environments, such as woods, bark, flowers and leaves of eucalyptus trees, in soil, and in bird droppings (Dhamgaye, et al., 2015; Springer et al., 2017). Both C. neoformans and C. gattii grow in pigeon guano, however, C. gattii is unable to mate efficiently in this environment, unlike C. neoformans (Lin et al., 2005). The cryptococcosis is initiated through exposure to the fungus by inhalation of spores or dissected yeast cells resulting, mainly, in a primary pulmonary infection that can remain latent for a long period. However, especially in immunocompromised individuals, it can emerge and spread from primary pulmonary foci by hematogenous route and reaching the central nervous system, causing meningitis, which is facilitated by fungal cell virulence factors (Temfack et al., 2019; Srikanta et al., 2014).

Cryptococcal virulence depends on conditions such as adaptation to the host environment, mechanisms of immune evasion and production of virulence factors (Zaragoza et al., 2019). Host survival involves the induction of mechanisms of adaptation to physiological temperature, different sources of nutrients, $\mathrm{pH}$ and oxidative stress. Virulence factors include the production of extracellular enzymes such as proteinases, lipases, and urease. Both urease and phospholipase B are degradation enzymes that play an important role in the pathogenicity of Cryptococcus spp., acting in their migration from the lung to the brain. The production of melanin is also essential to ensure the survival of the fungus within macrophages to provide protection to this pathogen against the host's immune response and to antifungals. The polysaccharide capsule that surrounds the cell body of Cryptococcus spp. is able to protect the cell from desiccation and oxidative stress in addition to protect against the host's immune responses, being able to inhibit the migration of neutrophils in different ways (Dong \& Murphy, 1993; Kwon-Chung et al., 2014; Azevedo, Rizzo, Rodrigues, 2016; Casadevall et al., 2019).

This disease is considered a public health problem and gets even more alarming because of the limitations in the use of antimicrobials to its treatment once that the therapeutic options available for this mycosis are becoming restricted due to the increase in fungal resistance and the high toxicity caused by some medicines, such as amphotericin B (AMB) (Nobrega et al.,2016; Folly et al., 2020). Cryptococcus spp. are able to develop different resistance mechanisms such as increasing in the expression of efflux pumps, overexpressing or expression of altered antimicrobial targets, and biofilm formation (Kumari et al., 2017; Yu et al., 2020). In the research for new antifungals, many plants have been evaluated (Mostafa et al, 2017) and studies have described the antimicrobial efficacy of natural compounds on Cryptococcus spp., inhibiting their growth (Pattoo, Belewa, Somai 2019), altering resistance factors and even causing their death (Bresciani et al. 2020). These findings suggest that plant derivatives may become potent allies in the alternative treatment of this infection. In this sense, the present study sought to survey the resistance mechanisms of Cryptococcus spp. against the main drugs used in cryptococcosis treatment as well as describing the antimicrobial activities of plants against these fungus species.

\section{Methodology}

The present study has an exploratory character and was developed according to Gil (2002) where a bibliographic research was carried out through scientific articles in English, Spanish and Portuguese. The following search keys were used: resistance factors of Cryptococcus spp., capsule of Cryptococcus spp., fungi drug target, role of efflux pump in Cryptococcus spp. drug resistance, among others. The platforms used were Scielo, PubMed, Redalyc and Periódicos CAPES. As an inclusion criterion, only articles containing the subjects relevant to the research were used. After selecting the papers, exploratory, selective reading and recording of information were performed. 


\section{Results and Discussion}

\subsection{Usual treatment of Cryptococcosis}

To understand the resistance mechanisms of Cryptococcus spp., it is important to know which drugs are involved in the treatment of cryptococcosis and how they achieve effectiveness in preventing outbreaks of this disease. In this sense, three main drugs that may be administered alone or in combination to handling cryptococcosis are: AMB, 5-flucytosine (5-FC) and fluconazole. Their administration is based on three steps (induction, consolidation, and maintenance) and it will depend on the patient's clinical condition (Brizendine et al., 2010; Sloan et al., 2014). For example, for patients with cryptococcal meningitis, the therapy consists of inducing intravenous AMB in combination with 5-FC for two weeks. After the induction phase, oral administration of fluconazole for 8 weeks (consolidation phase) is recommended and in the maintenance phase, there is a decrease in the dose of fluconazole that should be administered over a period of 6 to 12 months (Molloy et al., 2018; WHO, 2018). In the case of infections that present moderate to mild clinical manifestations, such as pulmonary cryptococcosis, drug intervention consists of the prescription of oral doses of fluconazole or voriconazole for up to 8 or 12 months (Spadari et al., 2020).

The combination of AMB and 5-FC is considered a standard of efficacy for therapies against cryptococcosis. The AMB fungicidal potential is due to its ability to bind the ergosterol present in the fungal cell membrane promoting a disturbance in this structure, causing extravasation of the intracellular content (Perfect et al., 2015; Liu et al., 2017; Kristanc et al., 2019). Beyond that, AMB can also induce a strong intracellular oxidative burst in the fungal cells (Sangalli et al., 2011). In relation to 5-FC, when converted into 5-fluorouracil within fungal cells, it plays an antifungal role by inhibiting the synthesis of nucleic acids and fungal proteins (Chandra \& Ghannoum, 2017). Fluconazole and AMB have already been used together to treat cryptococcal meningitis (Larsen et al., 2004). However, the combination of these two drugs raises some concerns once that it action could lead to an antagonistic interaction (Santos et al., 2012).

In addition, the main mechanism of action presented by fluconazole is the inhibition of fungal sterol 14-alphadesmethylase, a microsomal enzyme of the cytochrome P450 system (Correa et al., 2011), which is expressed by the erg 11 gene in Cryptococcus spp. (Sionov et al., 2010). Therefore, it compromises the biosynthesis of ergosterol in the cytoplasmic membrane, which leads to the accumulation of 14-alpha-methyl ester. Thus, those molecules can compromise the function of certain enzyme systems linked to the membrane, such as ATPase and enzymes of the electron transport system, inhibiting the growth of fungi and causing his death (Park et al., 2007; Bennett, 2003).

It is important to note that the mortality rate related to cryptococcosis is mainly associated with the ineffectiveness and toxicity of the drugs used and the high rate of development of pathogen resistance, increasing the need to develop new and safer antimicrobial drugs (Ribeiro et al., 2019). AMB is associated, for example, with a high level of nephrotoxicity in the hosts of Cryptococcus spp. which decreases renal function and lead to hypokalemia, generally requiring supplementation with potassium chloride (Kato et al., 2018; Personette et al., 2019). In addition, a study reports that 5-FC induces fetal skeletal malformations in rats by altering expression of homeobox genes (Kumamoto et al., 2020). Other studies report possible teratogenic effects of 5-FC (Chaube et al., 1969; Ohmori et al., 1972).

\subsection{Main resistance mechanisms of Cryptococcus spp.}

The increase in resistant cryptococcal strains to antimicrobials has been registered in recent years, mainly induced by the selective pressure exerted by the drugs most frequently used for antimicrobial treatments (Estrela, 2018). The excessive and/or inappropriate use of antifungals can favor the survival and spread of resistant isolates. The resistance mechanisms are 
multifactorial, involving drug, host, and pathogen characteristics (Sanglard et al., 2009; Perling et al., 2015; Hendrickson et al., 2019).

In general, microbial resistance can be classified in two ways: intrinsic resistance, when a species or strain shows resistance even though it has never been exposed to the drug (Kołaczkowska \& Kołaczkowski, 2016); and acquired, when antifungal resistance is demonstrated during exposure for a certain time to a medicine (White, 1998; Sanglard, 2016). Studies have described that several mechanisms may be involved in antifungal resistance to drugs, including drug degradation by enzymes, expression of efflux pumps and other drug transporters, changes in the drug target and/or implementation of alternative metabolic pathways (Figure 1) (Sionov et al., 2009; Flowers et al., 2012; Lockhart et al., 2017; Healey et al., 2018; Chowdhary et al., 2018; Stone et al., 2019).

Figure 1 - An overview of fungal cell membrane demonstrating some of the possible resistance mechanisms of Cryptoccocus spp. to antimicrobial drugs.

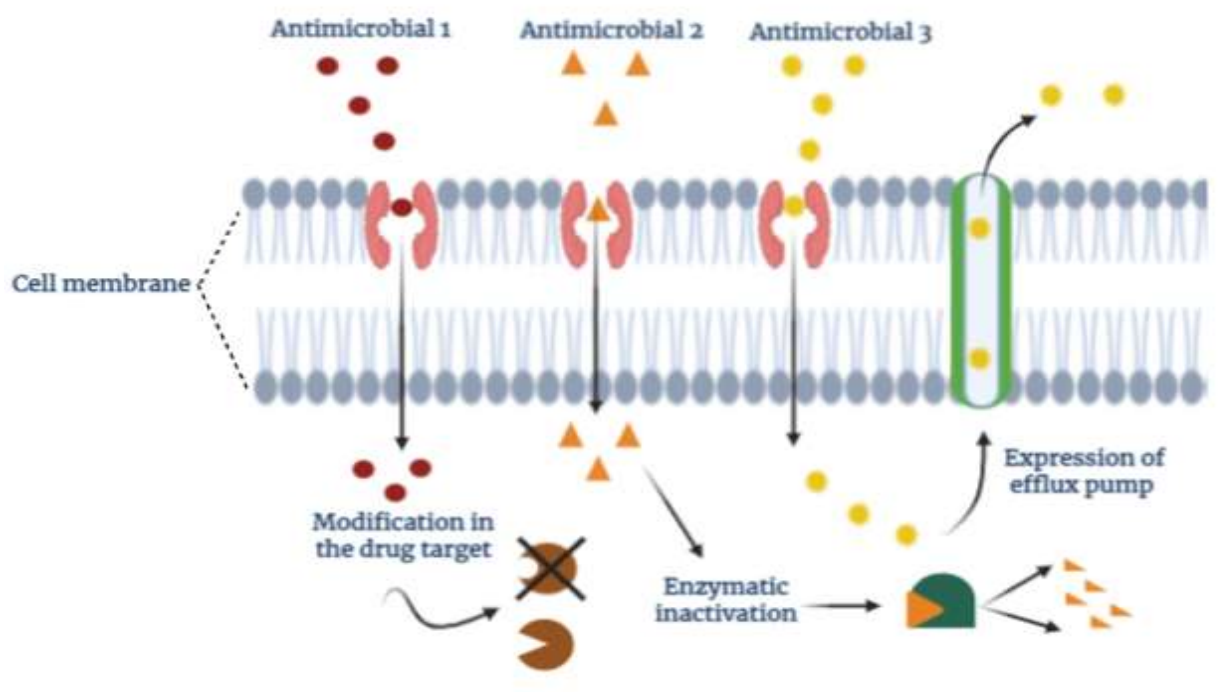

Source: The Authors (2021).

The upregulation of multidrug transporters, ATP-binding cassette transporters or multidrug efflux pumps (MEP) is a common mechanism of microbial resistance (Kano et al., 2017). The rapid efflux of drug-resistant strains can ensure that the drug does not accumulate in lethal levels to the cells. Cryptococcus spp. and other species of fungi shows transcriptional activation of the genes encoding efflux pump that often reduces the accumulation of medicines in the fungal cell, confirming the important role in drug tolerance and extrusion performed by efflux proteins (Sanguinetti et al., 2006; Prasad et al., 2014). In this sense, Basso et al. (2015) demonstrated that the afrl, mdrl and afr2 genes found in C. gatti and C. neoformans encode ABC transporters that are able to pump multiple azoles out of cells, thereby causing azole resistance. Sykes et al. (2015) reported an overexpression of the efflux pump PDR11 in C. gatti strains isolated from a patient after treatment with azoles. Reversion to wild-type susceptibility was observed when the strains were maintained in antifungal-free media confirming the in vivo development of heteroresistance. It is important to note that $C$. neoformans and $C$. gattii were the first fungi to be reported with antifungal heteroresistance, an intrinsic property of these species (Ben-Ami et al., 2016). A molecular mechanism of heteroresistance appears to involve the genes ergll and afrl (Stone et al., 2019). 
Research, Society and Development, v. 10, n. 2, e57810212819, 2021

(CC BY 4.0) | ISSN 2525-3409 | DOI: http://dx.doi.org/10.33448/rsd-v10i2.12819

The participation of efflux pumps in the resistance of Cryptococcus spp. was also evident when the deletion of the afrl gene in the strains of $C$. neoformans H99 and $C$. gattii R265 was made causing a drastic reduction in resistance to three xenobiotics and three triazoles, suggesting that AFR1 is the major drug efflux pump in both strains. In addition, fluconazole susceptibility was not affected when only AFR2 or MDR1 was deleted in both strains (Chang et al., 2018). Yang et al (2016) also reported a reduction in the minimal inhibitory concentration (MIC) of fluconazole when a wild-type strain of $C$. gatti (MIC: $32 \mu \mathrm{g} / \mathrm{ml}$ ) was compared with a strain that have a PDR11 deletion (MIC $0.03 \mu \mathrm{g} / \mathrm{ml}$ ). However, strains with the MDR1 deletion had no changes in their susceptibility. Posteraro et al. (2003) confirmed the participation of the ABC transporter-encoding gene (CnAFR1) in the resistance of $C$. neoformans strains to fluoconazole. A study also demonstrated that strains with atm 1 gene deletion were avirulent and more susceptible when compared to wild strains, which can be explained by the fact that the $\mathrm{ABC}$ transporter Atm1 participates in the production of fungus iron-sulfur clusters (Do et al., 2018).

Bastos et al. (2018) analyzed the resistance of $C$. neoformans H99 to tebuconazole, a fungicide largely used in Agriculture, later demonstrating that strains previously exposed to tebuconazole were more resistant to treatment with azoles. The authors' theory is that this tolerance to azole is due to the overexpression of the ERG11 and AFR1 (Bastos et al., 2018). Benomyl (BEN) is also a broad-spectrum fungicide used on several crops. In an in vivo test with strains of $C$. gatti with induced BEN-resistance, a cross-resistance to BEN and fluconazole was observed. Beyond that, BEN-resistant strain demonstrated to be hypervirulent in mice, leading to severe symptoms of cryptococcosis, early mortality and higher fungal burden in the organs, particularly on the brain. The strains showed increased expression of MDR1 genes (Carneiro et al., 2020).

It is important to note that the literature reports that a large part of the pesticides applied in crops are easily disposed in the environment causing several damages (Vander., 1996; Carvalho et al., 2017). In addition, excessive of pesticide rates have already been found in food (Wang et al., 2010; Bajwa et al., 2014). As seen previously, the use of some pesticides may be associated with the development of resistant microbial strains (Bastos et al., 2018; Carneiro et al., 2020).

Basidiomycetes such as Cryptococcus spp. have 9 to 10 genes that encode permeases (AAP and MUP), which are membrane transport proteins that have an important role in the resistance of microorganisms to antimicrobial agents (Fernandes et al., 2015). In this sense, Martho et al (2016) described the importance of two specific genes (aap4 and aap5) encoding permeases in Cryptococcus neoformans through the evaluation of the antimicrobial activity of eugenol from the essential oil of Pimenta dioica against four strains, being one wild (H99) and three mutants with deletions of single gene and double gene. When eugenol had its antimicrobial activity measured against the wild strain H99 it presented MIC of $0.4 \mu \mathrm{g} / \mu \mathrm{L}$ while against strains with deletion of the AAP4 and AAP5 separately it presented MIC of $1.6 \mu \mathrm{g} / \mu \mathrm{L}$ for both. When tested against strains with double deletion of these two genes, eugenol presented MIC of $3.1 \mu \mathrm{g} / \mu \mathrm{L}$ (Kamatou et al 2010). Thus, strains with double deletion showed more resistance than the others.

Flucytosine is one of the most widely used antifungal drugs for the treatment of cryptococcosis, although it is usually combined with AMB to minimize resistance development. The regulation and resistance mechanisms of $C$. neoformans to flucytosine are poorly understood (Jung et al., 2015; Bahn and Jung, 2013). In particular, two-component-like 2 (TCO2) is a unique sensor histidine kinase observed in C. neoformans, which carries two response modifiers and histidine kinase domains in a single polypeptide. The deletion of TCO2 gave $C$. neoformans a strong resistance to flucytosine, while the deletion of TCO1 increased the sensitivity to flucytosine, indicating that the pathogen adopts a two-component system to regulate the flucytosine response pathway (Zhang et al., 2002; Costa et al., 2015). Furthermore, since kinases can easily be inhibit by small molecules or antibodies they are considered to be the second largest protein class of drug targets (Rask et al., 2014)

Song et al. (2020) studying a transcription factor similar to APSES (Asm1p, Phd1p, Sok2p, Efg1p, and StuAp) called Mbs1 (Mbp1- and Swi4-like protein 1) revealed that Mbs1 was regulated in response to flucytosine in a Tco2/Hog1-dependent 
manner. Supporting this, C. neoformans with the deletion of MBS1 exhibited increased susceptibility to flucytosine. Intriguingly, Mbs1 played pleiotropic roles in diverse cellular processes of $C$. neoformans. Mbs1 positively regulated ergosterol biosynthesis and thereby affected polyene and azole drug susceptibility.

The mechanisms of AMB resistance are related to changes in the composition of ergosterol in the fungal cell caused by greater production of other sterols for which azoles have low affinity (Branco et al., 2017). Authors reported that this change may be mediated by mutations leading to defects in ergosterol biosynthesis or in catalase activity (Rodríguez, 1997; Berman, 2020). The azole antifungals act by inhibiting the enzyme required for the ergosterol pathway dependent on cytochrome P450 lanosterol 14-a-demethylase, encoded by the erg 11 gene in yeasts. Depletion of this pathway disrupts the production of ergosterol resulting in an accumulation of toxic intermediate sterols that causes structural and functional damage to the membrane and prevents the growth of fungi (Robbins et al., 2017). Alteration or overexpression of the ergl1 gene is one of the most prevalent mechanisms of resistance to azoles. Sterol regulatory elements, such as the transcription factor Sre1 in Cryptococcus neoformans, have also been described for their responses to antifungal drugs and virulence (Willger et al., 2008; Yu et al., 2020).

Besides that, resistance mediated by changes in the erg 11 gene that cause overexpression and accumulation of Erg $11 \mathrm{p}$ protein culminates in the activation of azole efflux pumps, whose activities in turn prevent the accumulation of azoles in yeast cells. Yeasts have high genomic plasticity, mainly Cryptococcus spp. and Candida albicans. This plasticity results in several changes in the cell, which affect the drug pump, the expression of the drug target, or both, causing resistance to antimicrobials and demonstrating that more than one resistance mechanism can be present in fungal strains (Selmecki et al., 2006; Kano et al., 2017).

Changes in the rates of carbon, nitrogen and oxygen in the fungal cell prevent the drugs from internalizing, which results in a mechanism of reduced susceptibility of Cryptococcus spp. cells to several antimicrobial drugs (Smith et al., 2019). In addition, caspofungin and AMB have their efficiency reduced due to the melanization of Cryptococcus spp. cell, which occurs during the infection process to the host (Schultzhaus et al., 2019). It is believed that melanin not only increase the virulence of microorganisms by reducing the susceptibility of pathogens to antimicrobial but also affect the host's immune response to the infection (Nosanchuk et al., 2015).

Furthermore, Ikeda et al. (2003) reported in an AMB time-kill study with C. neoformans, that significantly greater amounts of surviving melanized cells were observed in the first hours. In addition, fluorescence microscopy and flow cytometry analyzes showed that fewer melanized cells were stained with the fluorescent dye MitoRed. The authors suggested that melanin favors the deposit of the antimicrobial drug on the cell wall, reducing its penetration and effective concentrations.

The echinocandins target $\beta$-1,3-glucan synthase, which synthesizes the key cell wall component $\beta$-1,3-glucan. Nevertheless, this drug class is ineffective against Cryptococcus species (Denning, 2003; Chen et al., 2011; Perlin, 2015). C. neoformans shows innate resistance to echinocandins. This resistance mechanism is not yet well defined (Pinalto et al., 2019), however does not appear to be due to alterations of the biosynthetic pathway of $\beta$-glucans (Baker and Haugen, 1955; Reese et al., 2007). This affirmation is supported by the fact that echinocandins are able to bind to the cryptococcal cell wall in vitro (Casadevall, 1997; Park et al., 2009). One possible explanation for the lack of efficacy in vivo of echinocandins is the melanization once that the cell wall associated with melanin may prevent the drug reaching the enzymatic target on the yeast (Nosanchuk et al, 2006; Sitapati et al., 2010; Scemla et al., 2015). Several studies also describe the important role that melanin plays on Cryptococcus spp. resistance to antimicrobial drugs (Van Duin et al., 2002; Liaw et al., 2010; Brilhante et al., 2020; Banerjee et al., 2020).

Another important drug resistance mechanism is the microorganism's ability to form biofilm (Kumari et al., 2017). Biofilm effectively reduces the bioavailability of antimicrobial compounds, since the glucan matrix that surrounds the biofilm 
Research, Society and Development, v. 10, n. 2, e57810212819, 2021

(CC BY 4.0) | ISSN 2525-3409 | DOI: http://dx.doi.org/10.33448/rsd-v10i2.12819

can act as a barrier for these drugs. Other factors such as changes in stress response profiles, and in the cell membrane or wall also contribute to the increased resistance of these communities (Brilhante et al., 2020). Martinez et al. (2006) reported that biofilms produced by $C$. neoformans strains were significantly more resistant to AMB and caspofungin when compared to $C$. neoformans free cells, beyond that their susceptibilities to these drugs were further reduced if cryptococcal cells contained melanin. Sreejith et al. (2012) Martinez et al. (2015) and Villis et al. (2021) also described the importance of biofilm formation in the resistance of Cryptococcus spp. to antimicrobials. In addition, a study reports that strains of Cryptococcus spp. resistant to 5-FC showed hypermutations in known resistant genes (furl and fcy2) and in uxs 1 gene. Mutations of the uxs 1 gene cause the accumulation of UDP-glucuronic acid and changes in nucleotide metabolism, which appear to suppress the toxicity of 5fluorocytosine and its toxic derivative (5-fluorouracil) (Billmyre et al., 2020).

\subsection{Use of plants against Cryptococcus spp.}

In view of the above, it is necessary to study new alternatives with regard to the treatment of cryptococcal infections. It is important to note that plants play an important role in the health care population, mainly in societies present in underdeveloped countries, being an important tool for who do not have easy access to conventional health systems (Freitas et al., 2020). In this sense, medicinal plants have shown several biological activities, including antimicrobial potential (Anyanwu et al., 2017; Mostafa et al., 2018; Sabo et al., 2019). This fact may represent a way out of the public health problem that arose with the ability of those microorganisms to resist the main antimicrobials available, beyond the toxicity of those medicines (Masoumian et al., 2017; Chakraborty et al., 2018).

\subsubsection{Extracts and essential oils of plants with anti-cryptococcal activity}

The literature reports anti-cryptococcal activities of plants extracts (Table 1) and essential oils (Table 2). Bresciani et al. (2020) reported the fungistatic activity of the aqueous extract of the seeds of Allamanda polyantha (ASEAP). ASEAP presented a MIC of 70, 36 and $563 \mu \mathrm{g} / \mathrm{ml}$ for strains R265, 5272 and $\mathrm{H} 99$ respectively, where R265 and 5272 corresponded to C. gatti strains and H99 to C. neoformans. In addition, ASEAP inhibited the formation of the capsule by H99 strain beyond to cause morphological alterations, with defects in bud detachment and nuclear fragmentation. Moreover, after incubation with ASEAP, both strains of $C$. gatti showed a decrease in cell size.

The ethanol extract of Eugenia caryophyllus and Acorus calamus showed a MIC of $2.43 \mathrm{mg} / \mathrm{ml} \mathrm{and} 3.02 \mathrm{mg} / \mathrm{ml}$ respectively against $C$. neformans. The minimum fungicidal concentration (MFC) was also determined, being $22.22 \mathrm{mg} / \mathrm{ml}$ to $E$. caryophyllus and $30.82 \mathrm{mg} / \mathrm{ml}$ to A. calamus (Thirach et al., 2003). Mokoka et al. (2010) analyzed the antimicrobial activity of alcoholic extracts from the leaves of ten African plants against $C$. neoformans. The extracts with the lowest MIC were those of Maytenus undata with MIC of $0.09 \mathrm{mg} / \mathrm{mL}$ after $24 \mathrm{~h}$ incubation and $0.18 \mathrm{mg} / \mathrm{mL}$ after $48 \mathrm{~h}$, followed by Croton sylvaticus extract with MIC of $0.07 \mathrm{mg} / \mathrm{mL}$ after $24 \mathrm{~h}$ of incubation and $0.36 \mathrm{mg} / \mathrm{ml}$ after $48 \mathrm{~h}$.

When evaluating the antimicrobial activity against $C$. neoformans of the ethanolic extracts of Cassia alata and Ocimum sanctum, Ranganathan \& Balajee (2000) found MIC values that ranged from 500 to $1000 \mathrm{mg} / \mathrm{ml}$. However, no MIC has been detected for $O$. sanctum up to a concentration of $1000 \mathrm{mg} / \mathrm{ml}$. The study also reported the increase of the anti-Cryptococcus activity when the extracts were combined presenting fungicidal and fungistatic activity in low concentrations. Lemos et al. (2005) reported the antimicrobial activity of the ethanolic extract from the leaves of another species of the genus $O c i m u m$ againts $C$. neoformans: the in vitro antifungal activity of Ocimum gratissimum extract against 25 strains of $C$. neoformans was detected, with MIC ranging from 250 to $1000 \mathrm{mg} / \mathrm{ml}$. 
The crude extracts of Pelargonium sidoides tuber and aerial tissues were fungicidal and fungistatic to C. neoformans, and the mode of action of these extracts does not seem to be associated with alteration of ergosterol biosynthesis. However, the extracts significantly reduced the activity of laccase and urease in addition to reducing the size of the fungal capsule (Samie et al., 2019). Besides that, extract from fruits of Terminalia bellerica was found to possess antifungal activity and have the potential to inhibit drug resistant fungal strains of Cryptococcus spp. (Valli et al., 2013).

When analyzing the antimicrobial activity of different plant extracts from the Brazilian Cerrado with widespread use, Albernaz et al. (2010) observed that the ethyl acetate extract of Spiranthera odoratissima leaves and the dichloromethane extract of Calophyllum brasiliense root wood were fungistatic against $C$. gattii LMGO01 with MIC of $1.95 \mu \mathrm{g} / \mathrm{mL}$ and $31.25 \mu \mathrm{g} / \mathrm{mL}$ respectively. In addition, the ethyl acetate extract of the roots of Diospyros hispida, were fungistatic. The hydroalcoholic extract of the bark from Hymenaea martiana was fungistatic to strains of $C$. neoformans and $C$. gatti with MIC that ranged between 4 and $16 \mu \mathrm{g} / \mathrm{ml}$ (Souza et al., 2010).

The evaluation of the methanolic extract of nine native plants from India against Cryptococcus spp. strains by the disc diffusion assay method showed that only the extract of the Trapa natans L. rind, at concentrations of 125 and $250 \mu \mathrm{g} / \mathrm{disc}$ and $125 \mu \mathrm{g} / \mathrm{disc}$, was able to form significant inhibition halos on Cryptococcus luteolus. In addition, only Saussurea lappa extract showed activity against C. neoformans (Parekh et al., 2008).

Table 1. Plant extracts with antimicrobial activity against Cryptococcus spp.

\begin{tabular}{|c|c|c|c|c|c|}
\hline Material & Solvent & $\begin{array}{l}\text { Plant species } \\
\text { (Plant part) }\end{array}$ & $\begin{array}{l}\text { Cryptococcus } \\
\text { species }\end{array}$ & Effects & Reference \\
\hline \multirow{6}{*}{ Crude extract } & Water & $\begin{array}{c}\text { Allamanda } \\
\text { polyantha } \\
\text { (Seeds) }\end{array}$ & $\begin{array}{c}\text { C. gatti } \\
\text { and } \\
\text { C. neoformans }\end{array}$ & $\begin{array}{l}\text { Growth inhibition, } \\
\text { decrease in cell size, } \\
\text { alteration in capsule } \\
\text { size, morphological } \\
\text { alterations in } \\
\text { general with defects } \\
\text { in bud detachment } \\
\text { and nuclear } \\
\text { fragmentation. }\end{array}$ & $\begin{array}{l}\text { Bresciani et } \\
\text { al. }(2020)\end{array}$ \\
\hline & $\begin{array}{l}\text { Hydroalcoholic } \\
\text { solution }\end{array}$ & $\begin{array}{c}\text { Hymenaea } \\
\text { martiana } \\
\underline{(\text { Bark })}\end{array}$ & & Growth inhibition & $\begin{array}{l}\text { Souza et al. } \\
\quad(2010)\end{array}$ \\
\hline & \multirow{4}{*}{$\begin{array}{l}\text { Ethyl acetate and } \\
\text { Dichloromethane }\end{array}$} & $\begin{array}{c}\text { Spiranthera } \\
\text { odoratissima } \\
\text { (Leaves) }\end{array}$ & \multirow{4}{*}{ C. gatti } & \multirow{4}{*}{ Growth inhibition } & \multirow{4}{*}{$\begin{array}{l}\text { Albernaz et } \\
\text { al. (2010) }\end{array}$} \\
\hline & & $\begin{array}{c}\text { Aspidosperma } \\
\text { tomentosum } \\
\text { (Leaves) }\end{array}$ & & & \\
\hline & & $\begin{array}{l}\text { Diospyros } \\
\text { hispida } \\
\text { ( } \underline{\text { Root }})\end{array}$ & & & \\
\hline & & $\begin{array}{l}\text { Calophyllum } \\
\text { brasiliense } \\
\text { (oot wood) }\end{array}$ & & & \\
\hline
\end{tabular}

Source: The authors, 2021

(Continuation of Table 1 on the next page) 
Research, Society and Development, v. 10, n. 2, e57810212819, 2021

(CC BY 4.0) | ISSN 2525-3409 | DOI: http://dx.doi.org/10.33448/rsd-v10i2.12819

\begin{tabular}{|c|c|c|c|c|c|}
\hline Material & Solvent & $\begin{array}{l}\text { Plant species } \\
\text { (Plant part) }\end{array}$ & $\begin{array}{l}\text { Cryptococcus } \\
\text { species }\end{array}$ & Effects & Reference \\
\hline \multirow{18}{*}{ Crude Extract } & \multirow[t]{2}{*}{ Methanol } & $\begin{array}{c}\text { Saussurea lappa } \\
\text { Costus } \\
\text { (oot) }\end{array}$ & \multirow{2}{*}{$\begin{array}{l}\text { C. luteolus } \\
\text { and } \\
\text { C. } \\
\text { neoformans }\end{array}$} & \multirow[t]{2}{*}{ Growth inhibition } & \multirow[t]{2}{*}{$\begin{array}{l}\text { Parekh et al. } \\
\text { (2008). }\end{array}$} \\
\hline & & $\begin{array}{l}\text { Trapa natans } \mathrm{L} \\
\quad(\underline{\text { Rind })}\end{array}$ & & & \\
\hline & \multirow{11}{*}{$\begin{array}{c}\text { Hexane, } \\
\text { Dichloromethane, } \\
\text { Acetone and } \\
\text { Methanol }\end{array}$} & $\begin{array}{l}\text { Cassine aethiopica } \\
\quad \text { (Leaves) }\end{array}$ & \multirow{16}{*}{$\begin{array}{c}C . \\
\text { neoformans }\end{array}$} & \multirow{11}{*}{ Growth inhibition. } & \multirow{11}{*}{$\begin{array}{l}\text { Mokoka et al. } \\
\text { (2010). }\end{array}$} \\
\hline & & $\begin{array}{l}\text { Maytenus undata } \\
\text { (Leaves) }\end{array}$ & & & \\
\hline & & $\begin{array}{l}\text { Celtis Africana } \\
\quad \text { (Leaves) }\end{array}$ & & & \\
\hline & & $\begin{array}{l}\text { Morus mesozygia } \\
\quad \text { (Leaves) }\end{array}$ & & & \\
\hline & & 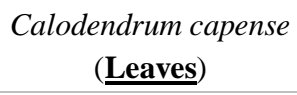 & & & \\
\hline & & $\begin{array}{c}\text { Zanthoxylum capense } \\
\text { (Leaves) }\end{array}$ & & & \\
\hline & & 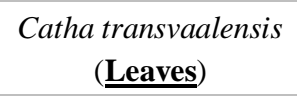 & & & \\
\hline & & $\begin{array}{l}\text { Cussonia zuluensis } \\
\text { (Leaves) }\end{array}$ & & & \\
\hline & & $\begin{array}{l}\text { Ochna natalitia } \\
\quad \text { (Leaves) }\end{array}$ & & & \\
\hline & & 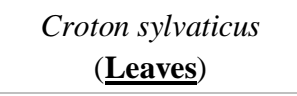 & & & \\
\hline & & 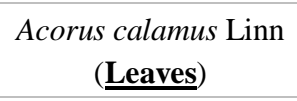 & & & \\
\hline & \multirow{5}{*}{ Ethanol } & $\begin{array}{c}\text { Eugenia caryophyllus } \\
\text { Bullock \& Harrison } \\
\text { (Leaves) }\end{array}$ & & $\begin{array}{l}\text { Growth inhibition and } \\
\text { fungicidal effect }\end{array}$ & $\begin{array}{l}\text { Thirach et al. } \\
\text { (2003). }\end{array}$ \\
\hline & & $\begin{array}{l}\text { Cassia alata } \\
\text { (Leaves) }\end{array}$ & & Growth inhibition & $\begin{array}{l}\text { Ranganathan \& } \\
\text { Balajee (2000). }\end{array}$ \\
\hline & & 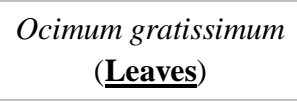 & & Growth inhibition & $\begin{array}{l}\text { Lemos et al. } \\
\text { (2005). }\end{array}$ \\
\hline & & $\begin{array}{l}\text { Terminalia bellerica } \\
\text { (年uits) }\end{array}$ & & $\begin{array}{l}\text { Growth inhibition and } \\
\text { synergic effect with } \\
\text { drugs }\end{array}$ & $\begin{array}{l}\text { Valli et al. } \\
\text { (2013). }\end{array}$ \\
\hline & & $\begin{array}{l}\text { Pelargonium sidoides } \\
\text { (Tuber and Aerial } \\
\text { parts })\end{array}$ & & $\begin{array}{l}\text { Growth inhibition and } \\
\text { fungicidal effect; } \\
\text { reduction of laccase and } \\
\text { urease activity; } \\
\text { reduction of the size of } \\
\text { fungal capsule }\end{array}$ & $\begin{array}{l}\text { Samie et al. } \\
\text { (2019). }\end{array}$ \\
\hline
\end{tabular}

Source: The authors, 2021

(Conclusion of table 1) 
The essential oils (EO) from Eucalyptus citriodora and Eucalyptus globulus presented moderate effect on $C$. neoformans with MIC of 0.5\% (w/v) (Luqman et al., 2008) and 0.13\% (w/v) (Suliman et al., 2010). Anti-Cryptococcus activity was also observed in the EO of the leaves of Citrus limon $(0.83 \mathrm{mg} / \mathrm{mL})$, Helichrysum kraussii $(1.0 \mathrm{mg} / \mathrm{mL})$, Lippia javanica $(0.25 \mathrm{mg} / \mathrm{mL})$ and Tetradenia riparia $(0.83 \mathrm{mg} / \mathrm{mL})$ (York et al., 2012). The EO of Laurus nobilis leaves also showed activity against $C$. neoformans with a MIC of $256 \mu \mathrm{g} / \mathrm{mL}$ and MFC of 1,024 $\mu \mathrm{g} / \mathrm{mL}$ (Pinheiro et al., 2017). EO from Thymus villosus subsp. lusitanicus was fungicidal and fungistatic against $C$. neoformans, probably due to rapid metabolic arrest and rupture of the pathogen plasma membrane (Pinto et al., 2013).

The EO of Apium graveolens L. (collected in Portugal and Italy), with sedanenolide, neocnidilide and neofitadiene as major components, presented different values of MIC and MFC for C. neoformans. Italian oil was more active with fungistatic and fungicidal values of $0.16 \mu \mathrm{g} / \mathrm{mL}$. To Portuguese oil, the MIC and MFC were 0.32 and $0.64 \mu \mathrm{g} / \mathrm{mL}$ respectively (Marongiu et al., 2013). The EO of Origanum vulgare, Pinus sylvestris and Thymus vulgaris had antimicrobial activity against six $C$. neoformans strains susceptible to azols and one resistant strain. In addition, the EO of the three plant species were synergistic when combined with itraconazole against $C$. neoformans strains susceptible to azole (Scalas et al., 2018).

EO of Oenanthe crocata from the aerial parts of the plant showed very low MIC for strains of C. neoformans with values ranging from 0.08 to $0.16 \mu \mathrm{L} / \mathrm{ml}$. The oil showed toxicity against macrophages and keratinocytes in the highest concentrations tested, but the oil was not cytotoxic at the MIC (Valentes et al., 2013). Similar to O. crocata, the EO of Salvia officinalis showed an antimicrobial effect against $C$. neoformans with no toxicity at MIC for macrophages and keratinocytes (Darwish et al., 2013); the same was reported for the EO of Angelica major (Cavaleiro et al., 2015). In addition, the essential oil of Mentha spicata presented a MIC of $0.32 \mu \mathrm{L} / \mathrm{mL}$ against $C$. neoformans (Piras et al., 2019). C. neoformans showed susceptibility also to Thapsia vilosa EO, with MIC of $0.16 \mu \mathrm{L} / \mathrm{ml}$ and no cytotoxic effect (Pinto et al., 2017).

Table 2. Essential oil with antimicrobial activity against Cryptococcus spp.

\begin{tabular}{|c|c|c|c|c|}
\hline Material & $\begin{array}{l}\text { Plant species } \\
\text { (Plant parts) }\end{array}$ & $\begin{array}{l}\text { Cryptococcus } \\
\text { species }\end{array}$ & Effects & Reference \\
\hline \multirow{7}{*}{ Essential Oil } & $\begin{array}{c}\text { Eucaliptus } \\
\text { citriodora } \\
\text { (Leaves) }\end{array}$ & \multirow{7}{*}{ C. neoformans } & \multirow{6}{*}{ Growth inhibition } & $\begin{array}{l}\text { Luqman et al. } \\
\qquad(2008) \text {. }\end{array}$ \\
\hline & $\begin{array}{l}\text { Eucaliptus globulus } \\
\text { (Leaves and steam) }\end{array}$ & & & $\begin{array}{l}\text { Suliman et al. } \\
\qquad \text { (2010). }\end{array}$ \\
\hline & $\begin{array}{l}\text { Citrus limon, } \\
\text { (Leaves) }\end{array}$ & & & \multirow{4}{*}{ York et al. (2012). } \\
\hline & 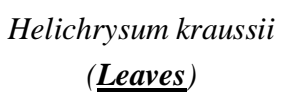 & & & \\
\hline & $\begin{array}{l}\text { Lippia javanica } \\
\quad(\underline{\text { Leaves }})\end{array}$ & & & \\
\hline & $\begin{array}{l}\text { Tetradenia riparia } \\
\qquad(\underline{\text { Leaves }})\end{array}$ & & & \\
\hline & $\begin{array}{l}\text { Laurus nobilis } \\
\qquad \text { (Leaves) }\end{array}$ & & $\begin{array}{l}\text { Growth inhibition and fungicidal } \\
\text { activity }\end{array}$ & $\begin{array}{l}\text { Pinheiro et al. } \\
\text { (2017). }\end{array}$ \\
\hline
\end{tabular}

Source: The authors (2021). NI: not informed by the author. (Continuation of table 2 on the next page). 


\begin{tabular}{|c|c|c|c|c|}
\hline Material & $\begin{array}{l}\text { Plant species } \\
\text { (Plant parts) }\end{array}$ & $\begin{array}{c}\text { Cryptococcus } \\
\text { species }\end{array}$ & Effects & Reference \\
\hline \multirow{8}{*}{ Essential oil } & $\begin{array}{c}\text { Pinus sylvestris } \\
(\underline{\mathbf{N I}}) \\
\text { Thymus vulgaris } \\
(\underline{\mathbf{N I}})\end{array}$ & \multirow{8}{*}{ C.neoformans } & \multirow{8}{*}{ Growth inhibition } & Scalas et al. (2018). \\
\hline & $\begin{array}{l}\text { Oenanthe crocata L } \\
\text { (杰rial parts) }\end{array}$ & & & $\begin{array}{l}\text { Valentes et al. } \\
\text { (2013). }\end{array}$ \\
\hline & $\begin{array}{l}\text { Salvia officinalis L } \\
\text { (包erial parts) }\end{array}$ & & & $\begin{array}{l}\text { Darwish et al. } \\
\text { (2013). }\end{array}$ \\
\hline & $\begin{array}{l}\text { Angelica major } \\
\text { (奋rial parts) }\end{array}$ & & & $\begin{array}{c}\text { Cavaleiro et al. } \\
\text { (2015). }\end{array}$ \\
\hline & $\begin{array}{c}\text { Mentha spicata } \\
(\underline{\underline{N I}})\end{array}$ & & & Piras et al. (2019). \\
\hline & $\begin{array}{l}\text { Thapsia vilosa } \\
\text { (Aerial parts) }\end{array}$ & & & Pinto et al. (2017). \\
\hline & $\begin{array}{l}\text { Apium graveolens } \\
\text { (Aerial parts) }\end{array}$ & & & $\begin{array}{l}\text { Marongiru et al. } \\
\text { (2013). }\end{array}$ \\
\hline & $\begin{array}{c}\text { Origanum vulgare } \\
(\underline{\underline{N}})\end{array}$ & & & Scalas et al. (2018). \\
\hline
\end{tabular}

Source: The authors, (2021). NI: not informed by the author (Conclusion of table 2).

\subsubsection{Natural compounds isolated from plants with antimicrobial activity against Cryptococcus}

Isolated phytoconstituents have shown antimicrobial activity against species of Cryptococcus (Table 3). Aurantiamide acetate (dipeptide), lupeol (triterpene), lespedin (flavonoid) and sitosterol 3-O- $\beta$-D-glucopyranoside (steroidal glycoside), compounds isolated from the aerial parts of Brillantaisia lamium, presented MIC of $12.5 \mu \mathrm{g} / \mathrm{mL}, 200 \mu \mathrm{g} / \mathrm{mL}, 6.25 \mu \mathrm{g} / \mathrm{mL}$ and $50 \mu \mathrm{g} / \mathrm{mL}$ and CMF of $25 \mu \mathrm{g} / \mathrm{mL}, 200 \mu \mathrm{g} / \mathrm{mL}, 12.5 \mu \mathrm{g} / \mathrm{mL}$ and $100 \mu \mathrm{g} / \mathrm{mL}$, respectively, against $C$. neoformans (Tamokou et al., 2011). In addition, two new antimicrobial peptides, called shepherin I and shepherin II, were isolated from the roots of Capsella brusa-pastoris. These peptides are constituted by 28 and 38 amino acids, respectively, rich in glycine and histidine and showed antimicrobial activity against $C$. neoformans with $\mathrm{IC}_{50}$ lower than than $2.5 \mu \mathrm{g} / \mathrm{mL}$ (Park et al., 2000).

The secondary metabolites maytinine and pristimerin, classified as quinone mehtide triterpenoids, were isolated from the bark of the Maytenus ilicifolia roots. These molecules showed excellent MIC against $C$. neoformans var. grubii, ranging from 0.48 to $3.9 \mathrm{mg} / \mathrm{L}$ for maytinine and 0.97 to $7.8 \mathrm{mg} / \mathrm{L}$ for pristimerin (Gullo et al., 2012).

Dihydropanaxacol, panaxacol, 1-hydroxididropanaxacol and 17-hydroxypanaxacol (polyacetylenes isolated from the root of Panax ginseng) showed antimicrobial activity against $C$. neoformans, with MIC values ranging from 250 to $1000 \mu \mathrm{g} / \mathrm{mL}$. The authors suggested that $P$. ginseng plants release antimicrobial polyacetylenes to the surrounding soil from the roots as defense compounds (Fukuyama et al., 2012).

Non-alkaloid compounds from Pterogyne nitens were also fungistatic agents against $C$. neoformans. Sorbifoline, a flavone derivative, exhibited a potent antifungal activity with MIC of $3.90 \mu \mathrm{g} / \mathrm{mL}$ against Cryptococcus gattii and a clinical isolate resistant to fluconazole of $C$. neoformans var. grubii. Pedalin and nitensoside $\mathrm{B}$, glycosylated derivatives of flavone, were slightly less active against $C$. neoformans (MIC $=7.80 \mu \mathrm{g} / \mathrm{mL}$ ) (Lima et al, 2016). 
Research, Society and Development, v. 10, n. 2, e57810212819, 2021

(CC BY 4.0) | ISSN 2525-3409 | DOI: http://dx.doi.org/10.33448/rsd-v10i2.12819

Cramoll lectin ( 0.93 to $120 \mu \mathrm{g} / \mathrm{mL}$ ), isolated from Cratylia mollis, inhibited the in vitro growth of C. gattii and showed to enhance the antimycotic effect of fluconazole (antifungal medication), clearly suggesting the effect of this lectin preventing the spread of fungal infection (Jandú et al., 2017).

ArtinM $(5.0 \mu \mathrm{g} / \mathrm{kg})$, lectin extracted from the seeds of Artorcapus heterophyllus, was able to reduce the pulmonary fungal load of $C$. gattii after 21 days of infection in a in vivo experiment. The therapeutic administration of ArtinM was also able to increase the absolute number of neutrophils and lymphocytes in the animals peripheral blood. It was also found that ArtinM in combination with fluconazole showed a reduction in pulmonary fungal load, being susceptible to association with conventional antifungal therapy (Brito, 2018).

Plumieride and plumieridine, iridoides isolated from ASEAP, were fungistatic and fungicidal against the strains H99, R265 and R272. MIC were lower for plumieride to all the 3 strains tested and incubation of the strains with this compound caused changes in cell morphology, while plumieridine did not alter the fungal cell structure. This find might indicate that plumieride is one of the compounds responsible for causing deformities in Cryptococcus spp. cells when ASEAP was tested, as mentioned above (Bresciani et al., 2020). Geranyl acetate, terpinen-4-ol, linalool and geraniol also showed antimicrobial activity against $C$. neoformans. The MIC ranged to 0.16 to $1.5 \mu \mathrm{L} / \mathrm{mL}$ and MFC 0.16 to $2.5 \mu \mathrm{L} / \mathrm{mL}$ (Pinto et al., 2013)

Eugenol, major constituent of the essential oil of $O$. gratissimum showed antimicrobial activity against 25 strains of $C$. neoformans with MIC that ranged from 0.9 to $250 \mu \mathrm{g} / \mathrm{ml}$. In addition to being fungicide, eugenol is associated with the reduced expression of the cxtlp gene. In addition, $C$. neoformans was more susceptible when eugenol was combined with fluoconazole (Parviz et al., 2020).

Carvacrol showed antifungal activity against $C$. neoformans binding to exogenous ergosterol and cholesterol, causing instability of the cell membrane (Nóbrega et al., 2016). Kumaria et al. (2017) reported that, among six active compounds extracted from essential oils, thymol (from thyme oil), carvracol (from oregano oil), and citral (from lemongrass oil) were the most effective compounds in terms of antibiofilm activity against Cryptococcus laurentii and $C$. neoformans. Through scanning electron microscopy (SEM) and confocal laser scanning microscopy (CLSM), it was observed that these compounds acted on biofilms promoting reduction in cellular density, alteration in the surface morphology of cells, and reduction of extracellular polymeric matrix. Thymol and carvacrol were also the most efficient in terms of human safety in the model of keratinocyteCryptococcus ssp. co-culture infection.

Compounds of leaf extract of Eremophila alternifolia were isolated and evaluated against C. gattii and C. neorformans. The diterpene compound 8,19-dihydroxyserrulat-14-ene was the most effective, presenting a MIC comparable to that of AMB (Hossain et al., 2019). Proanthocyanidin and polymeric tannins from Stryphnodendron adstringens showed antimicrobial activity against $C$. neoformans being able to reduce the size of the capsule, causing ultrastructural alterations such as cell wall disruption, mitochondria swelling, increase in the number of cytoplasmic vacuoles and formation of membranous structures in the cytoplasm. Beyond that, a decrease in capsular pigmentation of strains treated with this tannin was observed; however, proanthocyanidin did not interfere with the melanization of mammalian cells (Ishida et al., 2009). In mammals the melanization plays a role in protection from solar radiation and in skin and hair pigmentation (Sheehan et al., 2018). 
Research, Society and Development, v. 10, n. 2, e57810212819, 2021

(CC BY 4.0) | ISSN 2525-3409 | DOI: http://dx.doi.org/10.33448/rsd-v10i2.12819

Table 3 - Phytoconstituents with antimicrobial activity against Cry.ptococcus spp.

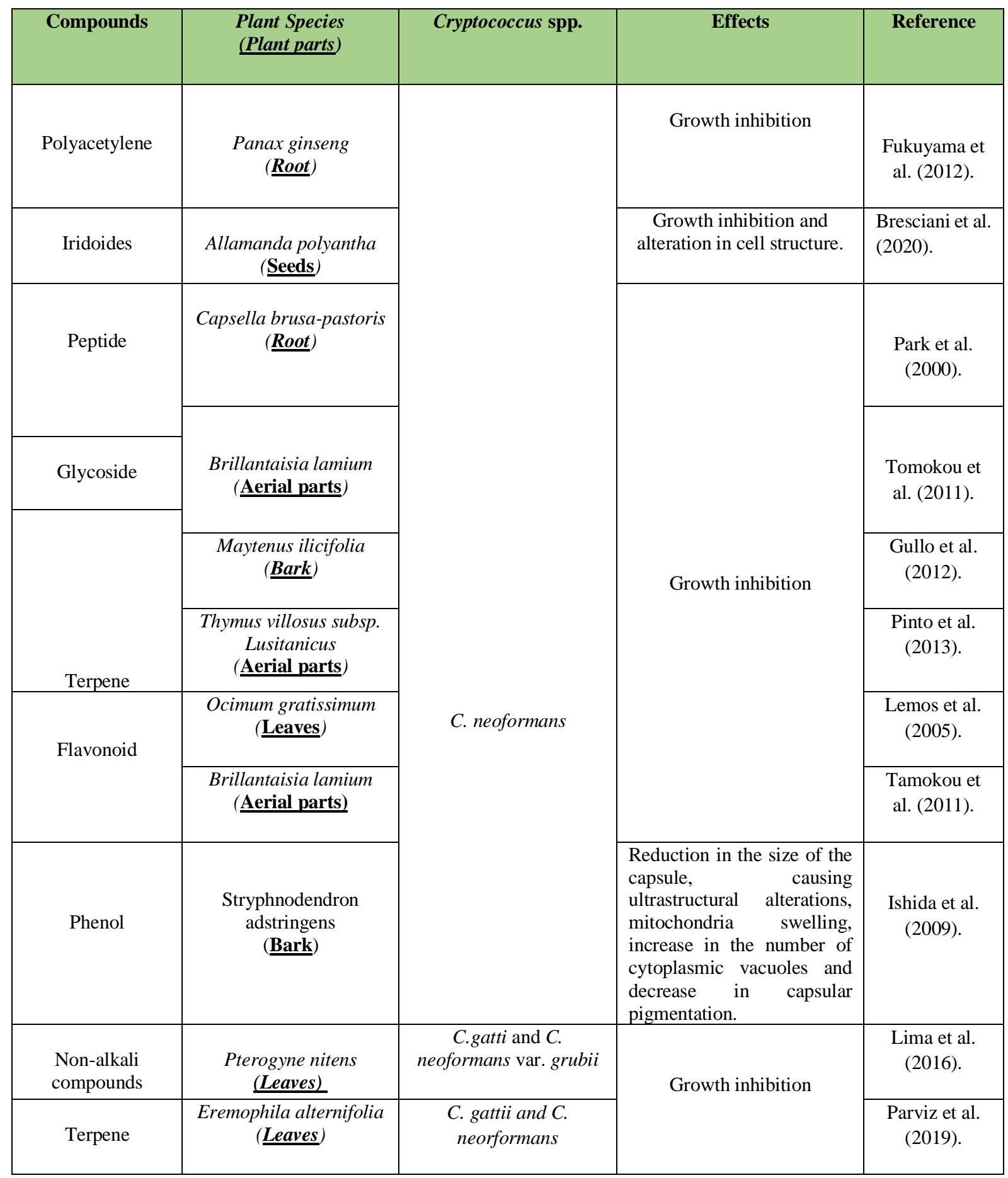

Source: The Authors, (2021).

(Continuation of table 3 on the next page) 
Research, Society and Development, v. 10, n. 2, e57810212819, 2021

(CC BY 4.0) | ISSN 2525-3409 | DOI: http://dx.doi.org/10.33448/rsd-v10i2.12819

\begin{tabular}{|c|c|c|c|c|}
\hline Compounds & $\begin{array}{c}\text { Plant Species } \\
\text { (Plant parts })\end{array}$ & $\begin{array}{c}\text { Cryptococcus } \\
\text { spp. }\end{array}$ & Reference \\
\hline \multirow{3}{*}{ Lectin } & $\begin{array}{c}\text { Cratylia mollis } \\
(\text { Seeds })\end{array}$ & \multirow{2}{*}{ C. gatti } & $\begin{array}{l}\text { Growth inhibition in infected mice } \\
\text { with potential synergistic effect }\end{array}$ & $\begin{array}{c}\text { Jandú et al., } \\
2017 .\end{array}$ \\
\cline { 2 - 4 } & $\begin{array}{c}\text { Artorcapus } \\
\text { heterophyllus } \\
\text { (Seeds) }\end{array}$ & $\begin{array}{l}\text { Reduction of pulmonary fungal } \\
\text { load with increased defense cells } \\
\text { and potential synergistic effect }\end{array}$ & Brito, 2018 \\
\hline
\end{tabular}

Source: The Authors (2021).

(Conclusion of table 3)

\subsubsection{Other antimicrobial mechanisms described for plants and their compounds}

The biological activities triggered by plants are associated with the presence of primary and secondary metabolites in these organisms, including flavonoids, saponins, tannins, phenols, proteins, carbohydrates, among others (Silva et al., 2010; Cioch et al., 2017). Antimicrobial substances and molecules extracted from plants can culminate in the inhibition and/or death of pathogens of the Cryptococcus genus through: morphological changes (Bresiani et all., 2020), inhibition of ergosterol production (Hossain et al., 2019), cell leakage (Lim et al., 1998; Thirach et al., 2003), capsular decrease (Samie et al., 2019; Ishida et al., 2009), interference in cell division, reduced activity of several enzymes such as laccase and urease (Sooksringam, 1985; Samie et al., 2019), inhibition of biofilm formation (Kumari et al., 2017), among others.

These mechanisms of action are usually triggered through the interaction of bioactive compounds from plants with cell components in fungal wall and membrane such as ergosterol (Oliveira et al., 2016). This interaction can lead to changes in cell permeability, interfering with the entrance of nutrients, making cell integrity unfeasible, as well as inhibiting the biosynthesis of cell wall components such as chitin, glucans and mannoproteins (Fernandes et al., 2007; Chen et al., 2013; Almeida et al., 2014).

In addition to the bioactive compounds mentioned above, the peptides also have antimicrobial activity. Peptides can induce cell leakage by interacting laterally with each other, forming structures similar to the protein channels present in the fungal membrane, facilitating the output of cellular content and causing the death of pathogens; this model of action is called "barrel-stave". Beyond that, there is the "carpet" form of action, in which the permeabilization and destabilization of the membrane occurs after the interaction of the positively charged peptides with the negative regions present in the phospholipid layer of the membrane (Shai, 1999, Wimley, 2010). Antimicrobial peptides can also target intracellular components (Brötz et al., 1998) accumulating in cytoplasm with consequent inhibition of RNA and DNA synthesis (Cho et al., 2009).

The antimicrobial mechanism of eugenol against fungi species is a well-discussed subject. Khatun et al. (2013) showed in their study with strains of Candida albicans that eugenol triggered harm effects to the fungal membrane by binding to ergosterol and simultaneously inhibiting the biosynthesis of this compound. However, Alves et al. (2017) reported in their study with Cryptococcus spp. that eugenol does not interfere with ergosterol content. The authors attribute the absence of this effect due to the encapsulated form of Cryptococcus spp., since the capsular polysaccharide gives the cell surface different physical and chemical properties that can interfere with the mechanism of action of eugenol. According to their results, Alves et al. (2017) proposed that eugenol induces the production of ROS (reactive oxygen species) and triggers disorders of the mitochondrial membrane in addition to reduces lysosomal integrity. Beyond that, eugenol can lead to lipid peroxidation, in which chains of free radicals "steal" electrons from the lipids of the cell membrane, causing cell damage. Carrasco et al. (2012) reported that an antimicrobial substance derived from eugenol, 4-allyl-2-methoxy-5-nitrophenol, shows no interference in the synthesis and/or organization of ergosterol.

Lectins are proteins that have specific and reversible affinity to carbohydrates, which allows these molecules to interact with glycoconjugates and polysaccharides in cell wall and membrane of pathogens, inhibiting the development of these 
microorganism through interference with cell homeostasis, spore germination and growth in general, which can culminate in its death (Paiva et al., 2010). Among the mechanisms of action found for lectins against different fungi, there are the ability to induce apoptosis and necrosis, inhibit biofilm production, induce oxidative stress, alter the cell membrane potential, cause lysosomal damage, among others (Silva et al. , 2018). It is also reported in literature the ability of lectin to induce an increase of DNase activity in fungi (Neto et al., 2015) as well as cause morphological changes such as disruption of the cell wall and reduction of cytoplasmic content (Procópio et al. , 2017).

\section{Conclusion}

The species of the Cryptococcus genus have different resistance mechanisms to the main antimicrobials used in their treatment. Such resistance irrupts in an alarming scenario within public health, making it necessary to search for tools that can be used to control and eradicate these pathogens. In this sense, essential oils, extracts and isolated molecules from plants have been shown as excellent research objects to aid in new alternative treatments of infections caused by these pathogens.

\section{References}

Abu-Darwish, M. T., Cabral, C., Ferreira, I. T., Gonçalves, M. J., Cavaleiro, C., Cruz, M. T., ... \& Salgueiro, L. (2013). Essential oil of common sage (Salvia officinalis L.) from Jordan: Assessment of safety in mammalian cells and its antifungal and anti-inflammatory potential. BioMed research international, 2013.

Ajesh, K., \& Sreejith, K. (2012). Cryptococcus laurentii biofilms: structure, development and antifungal drug resistance. Mycopathologia, 174(5-6), 409-419.

Albernaz, L. C., De Paula, J. E., Romero, G. A. S., Silva, M. D. R. R., Grellier, P., Mambu, L., \& Espindola, L. S. (2010). Investigation of plant extracts in traditional medicine of the Brazilian Cerrado against protozoans and yeasts. Journal of ethnopharmacology, 131(1), $116-121$.

Almeida Freires, I., Murata, R. M., Furletti, V. F., Sartoratto, A., de Alencar, S. M., Figueira, G. M., ... \& Rosalen, P. L. (2014). Coriandrum sativum L.(coriander) essential oil: antifungal activity and mode of action on Candida spp., and molecular targets affected in human whole-genome expression. PLoS One, $9(6)$, e99086.

Alspaugh, J. A. (2015). Virulence mechanisms and Cryptococcus neoformans pathogenesis. Fungal Genetics and Biology, 78, 55-58.

Alves, J. C., Ferreira, G. F., Santos, J. R., Silva, L. C., Rodrigues, J. F., Neto, W., ... \& Guzzo, L. S. (2017). Eugenol induces phenotypic alterations and increases the oxidative burst in Cryptococcus. Frontiers in microbiology, 8, 2419.

Anyanwu, M. U., \& Okoye, R. C. (2017). Antimicrobial activity of Nigerian medicinal plants. Journal of intercultural Ethnopharmacology, 6(2), 240.

Azevedo, R. V., Rizzo, J., \& Rodrigues, M. L. (2016). Virulence factors as targets for anticryptococcal therapy. Journal of fungi, 2 (4), 29.

Bahn, Y.-S.; Jung, K.-W. (2013). Stress signaling pathways for the pathogenicity of Cryptococcus. Eukaryotic cell, 12.12: 1564-1577. DOI: 10.1128/EC.0021813

Bajwa, U., \& Sandhu, K. S. (2014). Effect of handling and processing on pesticide residues in food-a review. Journal of food science and technology, 51(2), 201-220.

Baker, R. D., \& Haugen, R. K. (1955). Tissue changes and tissue diagnosis in cryptococcosis. A study of 26 cases. American journal of clinical pathology, 25(1).

Banerjee, A., Singh, A. D., Batabyal, K., Debnath, C., \& Samanta, I. (2020). Occurrence of Azole Resistant and Melanin Producing Cryptococcusneoformans in Wild Birds Kept in a Zoological Garden. Israel Journal of Veterinary Medicine, 75, 4.

Basso Jr, L. R., Gast, C. E., Bruzual, I., \& Wong, B. (2015). Identification and properties of plasma membrane azole efflux pumps from the pathogenic fungi Cryptococcus gattii and Cryptococcus neoformans. Journal of Antimicrobial Chemotherapy, 70(5), 1396-1407.

Bastos, R. W., Carneiro, H. C. S., Oliveira, L. V. N., Rocha, K. M., Freitas, G. J. C., Costa, M. C., ... \& Santos, D. A. (2018). Environmental triazole induces cross-resistance to clinical drugs and affects morphophysiology and virulence of Cryptococcus gattii and C. neoformans. Antimicrobial agents and chemotherapy, 62(1).

Ben-Ami, R., Zimmerman, O., Finn, T., Amit, S., Novikov, A., Wertheimer, N., ... \& Berman, J. (2016). Heteroresistance to fluconazole is a continuously distributed phenotype among Candida glabrata clinical strains associated with in vivo persistence. MBio, 7(4).

Bennett, E. J. Antimicrobianos (continuac,ao) Agentes antif ungicos. In ' As bases farmacologicas da terapêuticas; Gilman, A. G.; Goodman, L. S.; Gilman A., Ed.; McGraw-Hill Interamericana do Brasil: Rio de Janeiro, 2003; pp 975-979.

Berman, J., \& Krysan, D. J. (2020). Drug resistance and tolerance in fungi. Nature Reviews Microbiology, 1-13.

Billmyre, R. B., Clancey, S. A., Li, L. X., Doering, T. L., \& Heitman, J. (2020). 5-fluorocytosine resistance is associated with hypermutation and alterations in capsule biosynthesis in Cryptococcus. Nature communications, 11(1), 1-9. 
Branco, J., Ola, M., Silva, R. M., Fonseca, E., Gomes, N. C., Martins-Cruz, C., ... \& Miranda, I. M. (2017). Impact of ERG3 mutations and expression of ergosterol genes controlled by UPC2 and NDT80 in Candida parapsilosis azole resistance. Clinical Microbiology and Infection, 23(8), 575-e1.

Bresciani, F. R., Santi, L., Beys-da-Silva, W. O., Berger, M., Barcellos, V. D. A., Schripsema, J., ... \& Vainstein, M. H. (2020). Antifungal activity of Allamanda polyantha seed extract and its iridoids promote morphological alterations in Cryptococcus spp. Archiv der Pharmazie, 353(10), 2000133.

Brilhante, R. S. N., da Rocha, M. G., de Oliveira, J. S., Pereira-Neto, W. A., de Melo Guedes, G. M., de Aguiar Cordeiro, R., ... \& Castelo, D. D. S. C. M. (2020). Cryptococcus neoformans/Cryptococcus gattii species complex melanized by epinephrine: Increased yeast survival after amphotericin B exposure. Microbial pathogenesis, 143, 104123 .

Brilhante, R. S. N., Gotay, W. J. P., Pereira, V. S., de Oliveira, J. S., Pereira-Neto, W. A., Castelo-Branco, D. D. S. C. M., ... \& Rocha, M. F. G. (2020). Antifungal activity of promethazine and chlorpromazine against planktonic cells and biofilms of Cryptococcus neoformans/Cryptococcus gattii complex species. Medical Mycology.

Brito, P. K. M. O. A atividade imunomoduladora de ArtinM sobre o curso da infecção por Cryptococcus gattii (Doctoral dissertation, Universidade de São Paulo).

Brizendine, K. D., \& Pappas, P. G. (2010). Cryptococcal meningitis: current approaches to management in patients with and without AIDS. Current infectious disease reports, 12(4), 299-305.

Brötz, H., Bierbaum, G., Leopold, K., Reynolds, P. E., \& Sahl, H. G. (1998). The lantibiotic mersacidin inhibits peptidoglycan syn thesis by targeting lipid II. Antimicrobial agents and chemotherapy, 42(1), 154-160.

Carneiro, H. C. S., Bastos, R. W., Ribeiro, N. Q., Gouveia-Eufrasio, L., Costa, M. C., Magalhães, T. F. F., ... \& Santos, D. A. (2020). Hypervirulence and crossresistance to a clinical antifungal are induced by an environmental fungicide in Cryptococcus gattii. Science of The Total Environment, $740,140135$.

Carrasco, H., Raimondi, M., Svetaz, L., Liberto, M. D., Rodriguez, M. V., Espinoza, L., ... \& Zacchino, S. (2012). Antifungal activity of eugenol analogues. Influence of different substituents and studies on mechanism of action. Molecules, 17(1), 1002-1024.

Carvalho, F. P. (2017). Pesticides, environment, and food safety. Food and Energy Security, 6(2), 48-60.

Casadevall, A., Coelho, C., Cordero, R. J., Dragotakes, Q., Jung, E., Vij, R., \& Wear, M. P. (2019). The capsule of Cryptococcus neoformans. Virulence, 10(1), $822-831$.

Cavaleiro, C., Salgueiro, L., Gonçalves, M. J., Hrimpeng, K., Pinto, J., \& Pinto, E. (2015). Antifungal activity of the essential oil of Angelica major against Candida, Cryptococcus, Aspergillus and dermatophyte species. Journal of natural medicines, 69(2), 241-248.

Chakraborty, S., Afaq, N., Singh, N., \& Majumdar, S. (2018). Antimicrobial activity of Cannabis sativa, Thuja orientalis and Psidium guajava leaf extracts against methicillin-resistant Staphylococcus aureus. Journal of integrative medicine, 16(5), 350-357.

Chandra J., Ghannoum MA (2017) Flucytosine Treatment and Resistance Mechanisms. In: Mayers D., Sobel J., Ouellette M., Kaye K., March aim D. (eds) Antimicrobial Drug Resistance. Springer, Cham.https://doi.org/10.1007/978-3-319-46718-4_28

Chang, M., Sionov, E., Lamichhane, A. K., Kwon-Chung, K. J., \& Chang, Y. C. (2018). Roles of three Cryptococcus neoformans and Cryptococcus gattii efflux pump-coding genes in response to drug treatment. Antimicrobial agents and chemotherapy, 62(4).

Chaube, S., \& Murphy, M. L. (1969). The teratogenic effects of 5-fluorocytosine in the rat. Cancer research,29(3), $554-557$.

Chen, S. C. A., Slavin, M. A., \& Sorrell, T. C. (2011). Echinocandin antifungal drugs in fungal infections. Drugs, 71(1), 11-41.

Chen, Y., Zeng, H., Tian, J., Ban, X., Ma, B., \& Wang, Y. (2013). Antifungal mechanism of essential oil from Anethum graveolens seeds against Candida albicans. Journal of medical microbiology, 62(8), 1175-1183.

Cho, J. H., Sung, B. H., \& Kim, S. C. (2009). Buforins: histone H2A-derived antimicrobial peptides from toad stomach. Biochimica et Biophysica Acta (BBA)Biomembranes, 1788(8), 1564-1569.

Chowdhary, A., Prakash, A., Sharma, C., Kordalewska, M., Kumar, A., Sarma, S., .. \& Yadav, P. (2018). A multicentre study of antifungal susceptibility patterns among 350 Candida auris isolates (2009-17) in India: role of the ERG11 and FKS1 genes in azole and echinocandin resistance. Journal of Antimicrobial Chemotherapy, 73(4), 891-899.

Cioch, M., Satora, P. A. W. E. Ł., Skotniczny, M., Semik-Szczurak, D., \& Tarko, T. (2017). Characterisation of antimicrobial properties of extracts of selected medicinal plants. Polish journal of microbiology, 66(4), 463-472.

Corrêa, J. C. R., \& Salgado, H. R. N. (2011). Review of fluconazole properties and analytical methods for its determination. Critical reviews in analytical chemistry, 41(2), 124-132.

Costa, C.; et al (2015). New mechanisms of flucytosine resistance in C. glabrata unveiled by a chemogenomics analysis in S. cerevisiae. PloS one, 10.8: e0135110.

De Souza, A. C. M., Kato, L., Da Silva, C. C., Cidade, A. F., De Oliveira, C. M. A., \& Silva, M. D. R. R. (2010). Antimicrobial activity of Hymenaea martiana towards dermatophytes and Cryptococcus neoformans. Mycoses, 53(6), 500-503.

Denning, D. W. (2003). Echinocandin antifungal drugs. The Lancet, 362(9390), 1142-1151. 
Dhamgaye, S., L Murray, G., \& Peleg, A. Y. (2015). The influence of bacterial interaction on the virulence of Cryptococcus neoformans.

Do, E., Park, S., Li, M. H., Wang, J. M., Ding, C., Kronstad, J. W., \& Jung, W. H. (2018). The mitochondrial ABC transporter Atm1 plays a role in iron metabolism and virulence in the human fungal pathogen Cryptococcus neoformans. Medical mycology, 56(4), 458-468.

Dong, Z. M., \& Murphy, J. W. (1993). Mobility of human neutrophils in response to Cryptococcus neoformans cells, culture filtrate antigen, and individual components of the antigen. Infection and immunity, 61(12), 5067-5077.

Estrela, T. S. (2018). Resistência antimicrobiana: enfoque multilateral e resposta brasileira. Brasil, Ministério da Saúde, Assessoria de Assuntos Internacionais de Saúde. Saúde e Política Externa: os, 20, 1998-2018.

Fernandes, F. F., Dias, A. L. T., Ramos, C. L., Ikegaki, M., Siqueira, A. M. D., \& Franco, M. C. (2007). The" in vitro" antifungal activity evaluation of propolis G12 ethanol extract on Cryptococcus neoformans. Revista do Instituto de Medicina Tropical de São Paulo, 49(2), 93-95.

Flowers, S. A., Barker, K. S., Berkow, E. L., Toner, G., Chadwick, S. G., Gygax, S. E., ... \& Rogers, P. D. (2012). Gain-of-function mutations in UPC2 are a frequent cause of ERG11 upregulation in azole-resistant clinical isolates of Candida albicans. Eukaryotic cell, 11(10), 1289-1299.

Folly, M. L., Ferreira, G. F., Salvador, M. R., Sathler, A. A., da Silva, G. F., Santos, J. C. B., ... \& Lang, K. L. (2020). Evaluation of in vitro Antifungal Activity of Xylosma prockia (Turcz.) Turcz.(Salicaceae) Leaves Against Cryptococcus spp. Frontiers in microbiology, 10, 3114.

Fortwendel, J. R., Juvvadi, P. R., Pinchai, N., Perfect, B. Z., Alspaugh, J. A., Perfect, J. R., \& Steinbach, W. J. (2009). Differential effects of inhibiting chitin and 1,3- $\beta$-D-glucan synthesis in ras and calcineurin mutants of Aspergillus fumigatus. Antimicrobial agents and chemotherapy, 53(2), 476-482.

Freitas, A. F. S., Costa, W. K., Machado, J. C. B., Ferreira, M. R. A., Paiva, P. M. G., Medeiros, P. L., ... \& Napoleão, T. H. (2020). Toxicity assessment and antinociceptive activity of an ethanolic extract from Croton blanchetianus (Euphorbiaceae) leaves. South African Journal of Botany, 133, 30-39.

Fukuyama, N., Shibuya, M., \& Orihara, Y. (2012). Antimicrobial polyacetylenes from Panax ginseng hairy root culture. Chemical and Pharmaceutical Bulletin, 60(3), 377-380. DOI: $10.1248 / \mathrm{cpb} .60 .377$

Gil, A. C., \& Pessoni, A. (2020). Estratégias para o alcance de objetivos afetivos no ensino remoto. Revista Docência do Ensino Superior, 10, 1-18.

Gullo, F. P., Sardi, J. C., Santos, V. A., Sangalli-Leite, F., Pitangui, N. S., Rossi, S. A., Furlan, M. (2012). Antifungal activity of maytenin and pristimerin. Evidence-Based Complementary and Alternative Medicine, 2012. DOI: 10.1155/2012/340787

Hagen, F., Lumbsch, H. T., Arsenijevic, V. A., Badali, H., Bertout, S., Billmyre, R. B., \& Chaturvedi, S. (2017). Importance of resolving fungal nomenclature: the case of multiple pathogenic species in the Cryptococcus genus. Msphere, 2(4).

Healey, K. R., Kordalewska, M., Ortigosa, C. J., Singh, A., Berrío, I., Chowdhary, A., \& Perlin, D. S. (2018). Limited ERG11 mutations identified in isolates of Candida auris directly contribute to reduced azole susceptibility. Antimicrobial agents and chemotherapy, 62(10).

Hendrickson, J. A., Hu, C., Aitken, S. L., \& Beyda, N. (2019). Antifungal resistance: a concerning trend for the present and future. Current Infectious Disease Reports, 21(12), 47

Hossain, M. A., Biva, I. J., Kidd, S. E., Whittle, J. D., Griesser, H. J., \& Coad, B. R. (2019). Antifungal Activity in Compounds from the Australian Desert Plant Eremophila alternifolia with Potency Against Cryptococcus spp. Antibiotics, 8(2), 34.

Ikeda, R., Sugita, T., Jacobson, E. S., \& Shinoda, T. (2003). Effects of melanin upon susceptibility of Cryptococcus to antifungals. Microbiology and immunology, 47(4), 271-277.

Ishida, K., Rozental, S., de Mello, J. C. P., \& Nakamura, C. V. (2009). Activity of tannins from Stryphnodendron adstringens on Cryptococcus neoformans: effects on growth, capsule size and pigmentation. Annals of Clinical Microbiology and Antimicrobials, 8(1), 1-10.

Jandú, J. J., Costa, M. C., Santos, J. R., Andrade, F. M., Magalhães, T. F., Silva, M. V., Santos, D. A. (2017). Treatment with pCramoll alone and in combination with fluconazole provides therapeutic benefits in C. gattii infected mice. Frontiers in cellular and infection microbiology, 7, 211. DOI: $10.3389 /$ fcimb.2017.00211

Jung, K.-W.; et al (2015). Systematic functional profiling of transcription factor networks in Cryptococcus neoformans. Nature communications, 6.1: 1-14. DOI: $10.1038 /$ ncomms7757

Kamatou GP, Vermaak I, Viljoen AM (2012) Eugenol—from the remote Maluku Islands to the international market place: a review of a remarkable and versatile molecule. Molecules 17: 6953-6981. pmid:22728369

Kano, R., Okubo, M., Hasegawa, A., \& Kamata, H. (2017). Multi-azole-resistant strains of Cryptococcus neoformans var. grubii isolated from a FLZ-resistant strain by culturing in medium containing voriconazole. Medical Mycology, 55(8), 877-882.

Kato, H., Hagihara, M., Yamagishi, Y., Shibata, Y., Kato, Y., Furui, T., ... \& Mikamo, H. (2018). The evaluation of frequency of nephrotoxicity caused by liposomal amphotericin B. Journal of infection and chemotherapy, 24(9), 725-728.

Khan, M. S. A., Ahmad, I., \& Cameotra, S. S. (2013). Phenyl aldehyde and propanoids exert multiple sites of action towards cell membrane and cell wall targeting ergosterol in Candida albicans. Amb Express, 3(1), 1-16.

Kołaczkowska, A., \& Kołaczkowski, M. (2016). Drug resistance mechanisms and their regulation in non-albicans Candida species. Journal of Antimicrobial Chemotherapy, 71(6), 1438-1450. 
Research, Society and Development, v. 10, n. 2, e57810212819, 2021

(CC BY 4.0) | ISSN 2525-3409 | DOI: http://dx.doi.org/10.33448/rsd-v10i2.12819

Kristanc, L., Božič, B., Jokhadar, Š. Z., Dolenc, MS, \& Gomišček, G. (2019). The pore-forming action of polyenes: From model membranes to living organisms. Biochimica et biophysica acta. Biomembranes, 1861 (2), 418-430.https://doi.org/10.1016/j.bbamem.2018.11.006

Kumamoto, T., Senuma, M., Todoroki, M., Kumagai, F., Imai, H., Suzuki, R., ... \& Kuwagata, M. (2020). 5-Fluorocytosine induces fetal skeletal malformations in rats by altering expression of Homeobox genes. Fundamental Toxicological Sciences, 7(2), 97-103.

Kumari, P., Mishra, R., Arora, N., Chatrath, A., Gangwar, R., Roy, P., \& Prasad, R. (2017). Antifungal and anti-biofilm activity of essential oil active components against Cryptococcus neoformans and Cryptococcus laurentii. Frontiers in microbiology, 8, 2161.

Kwon-Chung, K. J., Fraser, J. A., Doering, T. L., Wang, Z. A., Janbon, G., Idnurm, A., \& Bahn, Y. S. (2014). Cryptococcus neoformans and Cryptococcus gattii, the etiologic agents of cryptococcosis. Cold Spring Harbor perspectives in medicine, 4(7), a019760.

Larsen, R. A., Bauer, M., Thomas, A. M., \& Graybill, J. R. (2004). Amphotericin B and fluconazole, a potent combination therapy for cryptococcal meningitis. Antimicrobial agents and chemotherapy, 48(3), 985-991.

Lemos, Janine de Aquino et al. Antifungal activity from Ocimum gratissimum L. towards Cryptococcus neoformans. Memórias do Instituto Oswaldo Cruz, v. 100, n. 1, p. $55-58,2005$.

Liaw, S. J., Wu, H. C., \& Hsueh, P. R. (2010). Microbiological characteristics of clinical isolates of Cryptococcus neoformans in Taiwan: serotypes, mating types, molecular types, virulence factors, and antifungal susceptibility. Clinical Microbiology and Infection, 16(6), 696-703.

Lima, C. S., Polaquini, C. R., dos Santos, M. B., Gullo, F. P., Leite, F. S., Scorzoni, L., Regasini, L. O. (2016). Anti-Candida and anti-Cryptococcus evaluation of 15 non-alkaloidal compounds from Pterogyne nitens. Asian Pacific Journal of Tropical Biomedicine, 6(10), 841-845. DOI: 10.1016/j.apjtb.2016.08.003

Liu, M., Chen, M., \& Yang, Z. (2017). Design of amphotericin B oral formulation for antifungal therapy. Drug delivery, 24 (1), 19.https://doi.org/10.1080/10717544.2016.1225852

Lockhart, S. R., Etienne, K. A., Vallabhaneni, S., Farooqi, J., Chowdhary, A., Govender, N. P., ... \& Berkow, E. L. (2017). Simultaneous emergence of multidrugresistant Candida auris on 3 continents confirmed by whole-genome sequencing and epidemiological analyses. Clinical Infectious Diseases, 64(2), 134-140.

Luqman, S., Dwivedi, G. R., Darokar, M. P., Kalra, A., \& Khanuja, S. P. S. (2008). Antimicrobial activity of Eucalyptus citriodora essential oil. International journal of essential oil therapeutics, 2(2), 69-75.

Marongiu, B., Piras, A., Porcedda, S., Falconieri, D., Maxia, A., Frau, M. A., Salgueiro, L. (2013). Isolation of the volatile fraction from Apium graveolens L. (Apiaceae) by supercritical carbon dioxide extraction and hydrodistillation: chemical composition and antifungal activity. Natural product research,27(17), 1521-1527. DOI: $10.1080 / 14786419.2012 .725402$

Martho, K. F. C., de Melo, A. T., Takahashi, J. P. F., Guerra, J. M., Santos, D. C. D. S., Purisco, S. U., ... \& Pascon, R. C. (2016). Amino acid permeases and virulence in Cryptococcus neoformans. PloS one, 11(10), e0163919.

Martinez, L. R., \& Casadevall, A. (2006). Susceptibility of Cryptococcus neoformans biofilms to antifungal agents in vitro. Antimicrobial agents and chemotherapy, 50(3), 1021-1033.

Martinez, L. R., \& Casadevall, A. (2015). Biofilm formation by Cryptococcus neoformans. Microbial Biofilms, 135-147.

Masoumian, M., \& Zandi, M. (2017). Antimicrobial activity of some medicinal plant extracts against multidrug resistant bacteria. Zahedan Journal of Research in Medical Sciences, $19(11)$.

Molloy, S. F., Kanyama, C., Heyderman, R. S., Loyse, A., Kouanfack, C., Chanda, D., ... \& Harrison, T. S. (2018). Antifungal combin ations for treatment of cryptococcal meningitis in Africa. New England Journal of Medicine, 378(11), 1004-1017.

Mostafa, A. A., Al-Askar, A. A., Almaary, K. S., Dawoud, T. M., Sholkamy, E. N., \& Bakri, M. M. (2018). Antimicrobial activity of some plant extracts against bacterial strains causing food poisoning diseases. Saudi Journal of Biological Sciences, 25(2), 361-366.

Nóbrega, R. D. O., Teixeira, A. P. D. C., Oliveira, W. A. D., Lima, E. D. O., \& Lima, I. O. (2016). Investigation of the antifungal activity of carvacrol against strains of Cryptococcus neoformans. Pharmaceutical biology, 54(11), 2591-2596.

Nosanchuk, J.D., and Casadevall, A. (2006) Impact of melanin on microbial virulence and clinical resistance to antimicrobial compounds. Antimicrob Agents chemother 50: $3519-3528$.

Ohmori, K. (1972). Teratogenic effects of 5-fluoro-2'-deox Yuridine in pregnant mice. Teratology, 5(1), 71-80.

Oliveira, L. B. S., Batista, A. H. M., Fernandes, F. C., Sales, G. W. P., \& Nogueira, N. A. P. (2016). Atividade antifúngica e possív el mecanismo de ação do óleo essencial de folhas de Ocimum gratissimum (Linn.) sobre espécies de Candida. Revista Brasileira de Plantas Medicinais, 18(2), 511-523.

Parekh, J., \& Chanda, S. (2008). In vitro antifungal activity of methanol extracts of some Indian medicinal plants against pathogen ic yeast and moulds. African journal of Biotechnology, 7(23)

Park, C. J., Park, C. B., Hong, S. S., Lee, H. S., Lee, S. Y., \& Kim, S. C. (2000). Characterization and cDNA cloning of two glycine-and histidine-rich antimicrobial peptides from the roots of shepherd's purse, Capsella bursa-pastoris. Plant Molecular Biology, 44(2), $187-197$.

Park, J. S.; Yu, K. A.; Kang, T. H.; Kim, S.; Suh, Y. G. Discovery of novel indazole-linked triazoles as antifungal agents. Bioorg. Med. Chem. Lett. 2007a, 17, 3486-3490. 
Research, Society and Development, v. 10, n. 2, e57810212819, 2021 (CC BY 4.0) | ISSN 2525-3409 | DOI: http://dx.doi.org/10.33448/rsd-v10i2.12819

Parviz, P., Shams-Ghahfarokhi, M., \& Razzaghi-Abyaneh, M. (2020). Antifungal activity of eugenol on Cryptococcus neoformans biological activity and Cxt1p gene expression. Current Medical Mycology, 6(1), 9.

Pattoo, M., Belewa, V., \& Somai, B. M. (2019). Phytochemical Constituents of Tulbaghia violacea Harv Extract and its Antifungal Potential Against Cryptococcus neoformans and Cryptococcus gattii. The Natural Products Journal, 9(4), 330-340.

Perfect, JR, \& Bicanic, T. (2015). Cryptococcosis diagnosis and treatment: What do we know now. Fungal genetics and biology: FG \& B, 78, 4954.https://doi.org/10.1016/j.fgb.2014.10.003

Perlin, D. S. (2015). Mechanisms of echinocandin antifungal drug resistance. Annals of the new York Academy of Sciences, 1354(1), 1.

Personett, H. A., Kayhart, B. M., Barreto, E. F., Tosh, P., Dierkhising, R., Mara, K., \& Leung, N. (2019). Renal recovery following liposomal amphotericin BInduced nephrotoxicity. International journal of nephrology, 2019.

Pinheiro, L. S., de Oliveira Filho, A. A., \& Guerra, F. Q. S. (2017). Antifungal activity of the essential oil isolated from Laurus nobilis L. against Cryptococcus neoformans strains. Journal of Applied Pharmaceutical Science, 7(05), 115-118. DOI: 10.7324/JAPS.2017.70520

Pinto, E., Gonçalves, M. J., Cavaleiro, C., \& Salgueiro, L. (2017). Antifungal activity of Thapsia villosa essential oil against Candida, Cryptococcus, Malassezia, Aspergillus and dermatophyte species. Molecules, 22(10), 1595.

Pinto, E., Gonçalves, M. J., Hrimpeng, K., Pinto, J., Vaz, S., Vale-Silva, L. A., Salgueiro, L. (2013). Antifungal activity of the essential oil of Thymus villosus subsp. lusitanicus against Candida, Cryptococcus, Aspergillus and dermatophyte species. Industrial Crops and Products, 51, 93-99. DOI: 10.1016/j.indcrop.2013.08.033

Piras, A., Porcedda, S., Falconieri, D., Maxia, A., Gonçalves, M., Cavaleiro, C., \& Salgueiro, L. (2019). Antifungal activity of essential oil from Mentha spicata L. and Mentha pulegium L. growing wild in Sardinia island (Italy). Natural product research, 1-7.

Posteraro, B., Sanguinetti, M., Sanglard, D., La Sorda, M., Boccia, S., Romano, L., ... \& Fadda, G. (2003). Identification and characterization of a Cryptococcus neoformans ATP binding cassette (ABC) transporter-encoding gene, CnAFR1, involved in the resistance to fluconazole. Molecular microbiology, 47(2), 357371.

Prasad, R., \& Rawal, M. K. (2014). Efflux pump proteins in antifungal resistance. Frontiers in pharmacology, 5, 202.

Procópio, T. F., de Siqueira Patriota, L. L., de Moura, M. C., da Silva, P. M., de Oliveira, A. P. S., do Nascimento Carvalho, L. V., ... \& Napoleão, T. H. (2017). CasuL: a new lectin isolated from Calliandra surinamensis leaf pinnulae with cytotoxicity to cancer cells, antimicrobial activity and antibiofilm effect. International journal of biological macromolecules, 98, 419-429.

Ranganathan, S., \& Balajee, S. A. M. (2000). Anti-Cryptococcus activity of combination of extracts of Cassia alata and Ocimum sanctum. Mycoses, 43(7-8), 299-301.

Rask-Andersen, M., Masuram, S., \& Schiöth, H. B. (2014). The druggable genome: evaluation of drug targets in clinical trials sugge sts major shifts in molecular class and indication. Annual review of pharmacology and toxicology, 54, 9-26.

Reese, Amy J. et al. Loss of cell wall alpha (1-3) glucan affects Cryptococcus neoformans from ultrastructure to virulence. Molecular microbiology, v. 63, n. 5, p. 1385-1398, 2007

Ribeiro, NQ, Santos, A., Emídio, E., Costa, MC, Freitas, G., Carmo, P., Silva, MF, de Brito, CB, de Souza, DG, Paixão, TA, \& Santos, DA (2019). Pioglitazone as an adjuvant of amphotericin B for the treatment of cryptococcosis. International journal of antimicrobial agents, 54 (3), 301308.https://doi.org/10.1016/j.ijantimicag.2019.06.020

Robbins, N., Caplan, T., \& Cowen, L. E. (2017). Molecular evolution of antifungal drug resistance. Annual review of microbiology, 71, 753-775.

Rodríguez, T. J. (1997). The resistance of opportunistic fungi to antifungals. Revista clinica espanola, 197, 67.

Sabo, V. A., Knezevic, P. (2019). Antimicrobial activity of Eucalyptus camaldulensis Dehn. plant extracts and essential oils: A review. Industrial crops and products, 132, 413-429. DOI: 10.1016/j.indcrop.2019.02.051

Samie, S., Trollope, K. M., Joubert, L. M., Makunga, N. P., \& Volschenk, H. (2019). The antifungal and Cryptococcus neoformans virulence attenuating activity of Pelargonium sidoides extracts. Journal of ethnopharmacology, 235, 122-132.

Sangalli-Leite, F., Scorzoni, L., Mesa-Arango, A. C., Casas, C., Herrero, E., Gianinni, M. J. S. M., ... \& Zaragoza, O. (2011). Amphotericin B mediates killing in Cryptococcus neoformans through the induction of a strong oxidative burst. Microbes and infection, 13(5), 457-467.

Sanglard, D. (2016). Emerging threats in antifungal-resistant fungal pathogens. Frontiers in medicine, 3, 11.

Sanglard, D., Coste, A., \& Ferrari, S. (2009). Antifungal drug resistance mechanisms in fungal pathogens from the perspective of tran scriptional gene regulation. FEMS yeast research, 9(7), 1029-1050.

Sanguinetti, M., Posteraro, B., La Sorda, M., Torelli, R., Fiori, B., Santangelo, R., ... \& Fadda, G. (2006). Role of AFR1, an ABC transporter-encoding gene, in the in vivo response to fluconazole and virulence of Cryptococcus neoformans. Infection and immunity, 74(2), 1352-1359.

Scalas, D., Mandras, N., Roana, J., Tardugno, R., Cuffini, A. M., Ghisetti, V., ... \& Tullio, V. (2018). Use of Pinus sylvestris L.(Pinaceae), Origanum vulgare L.(Lamiaceae), and Thymus vulgaris L.(Lamiaceae) essential oils and their main components to enhance itraconazole activity against azole susceptible/notsusceptible Cryptococcus neoformans strains. BMC complementary and alternative medicine, 18(1), 1-13. 
Research, Society and Development, v. 10, n. 2, e57810212819, 2021 (CC BY 4.0) | ISSN 2525-3409 | DOI: http://dx.doi.org/10.33448/rsd-v10i2.12819

Scemla, A., Gerber, S., Duquesne, A., Parize, P., Martinez, F., Anglicheau, D., ... \& Lortholary, O. (2015). Dramatic improvement of severe cryptococcosisinduced immune reconstitution syndrome with adalimumab in a renal transplant recipient. American Journal of Transplantation, 15(2), 560-564.

Schultzhaus, Z., Chen, A., Kim, S., Shuryak, I., Chang, M., \& Wang, Z. (2019). Transcriptomic analysis reveals the relationship of melanization to growth and resistance to gamma radiation in Cryptococcus neoformans. Environmental microbiology, 21(8), 2613-2628.

Selmecki, A., Forche, A., \& Berman, J. (2006). Aneuploidy and isochromosome formation in drug-resistant Candida albicans. Science, 313(5785), 367-370.

Shai, Y. (1999). Mechanism of the binding, insertion and destabilization of phospholipid bilayer membranes by $\alpha$-helical antimicrobial and cell non-selective membrane-lytic peptides. Biochimica et Biophysica Acta (BBA)-Biomembranes, 1462(1-2), 55-70.

Silva, N. C. C., \& Fernandes Júnior, A. J. J. O. V. A. (2010). Biological properties of medicinal plants: a review of their antimicrobial activity. Journal of venomous Animals and Toxins including tropical diseases, 16(3), 402-413.

Silva, P. M., de Moura, M. C., Gomes, F. S., da Silva Trentin, D., de Oliveira, A. P. S., de Mello, G. S. V., ... \& Napoleão, T. H. (2018). PgTeL, the lectin found in Punica granatum juice, is an antifungal agent against Candida albicans and Candida krusei. International journal of biological macromolecules, 108, 391-400.

Silva, T. C., de Ávila, R. I., Zara, A. L. S. A., Santos, A. S., Ataídes, F., Freitas, V. A. Q., ... \& Silva, M. D. R. R. (2020). Punicalagin triggers ergosterol biosynthesis disruption and cell cycle arrest in Cryptococcus gattii and Candida albicans. Brazilian Journal of Microbiology, 51(4), $1719-1727$.

Sionov, E., Chang, Y. C., Garraffo, H. M., \& Kwon-Chung, K. J. (2009). Heteroresistance to fluconazole in Cryptococcus neoformans is intrinsic and associated with virulence. Antimicrobial agents and chemotherapy, 53(7), 2804-2815.

Sionov, E., Chang, Y. C., Garraffo, H. M., Dolan, M. A., Ghannoum, M. A., \& Kwon-Chung, K. J. (2012). Identification of a Cryptococcus neoformans cytochrome P450 lanosterol 14 $\alpha$-demethylase (Erg11) residue critical for differential susceptibility between fluconazole/voriconazole and itraconazole/posaconazole. Antimicrobial agents and chemotherapy, 56(3), 1162-1169.

Sitapati, A. M., Kao, C. L., Cachay, E. R., Masoumi, H., Wallis, R. S., Mathews, W. C., \& Owen Clinic Study Group. (2010). Treatment of HIV-related inflammatory cerebral cryptococcoma with adalimumab. Clinical Infectious Diseases, 50(2), e7-e10.

Sloan, D. J., \& Parris, V. (2014). Cryptococcal meningitis: epidemiology and therapeutic options. Clinical epidemiology, 6, 169.

Smith, D. F., \& Casadevall, A. (2019). The role of melanin in fungal pathogenesis for animal hosts. Fungal Physiology and Immunopathogenesis, 1-30.

Song, M.-H.; et al (2012). A flucytosine-responsive Mbp1/Swi4-like protein, Mbs1, plays pleiotropic roles in antifungal drug resistance, stress response, and virulence of Cryptococcus neoformans. Eukaryotic cell, 11.1: 53-67. doi: 10.1128/EC.05236-117

Spadari, CC, Wirth, F., Lopes, LB, \& Ishida, K. (2020). New Approaches for Cryptococcosis Treatment. Microorganisms, 8 (4), 613.https://doi.org/10.3390/microorganisms 8040613

Springer, D. J., Mohan, R., \& Heitman, J. (2017). Plants promote mating and dispersal of the human pathogenic fungus Cryptococcus. PloS one, 12(2), e0171695. Srikanta, D., Santiago-Tirado, F. H., \& Doering, T. L. (2014). Cryptococcus neoformans: historical curiosity to modern pathogen. Yeast (Chichester, England), 31(2), 47-60.

Stone, N. R., Rhodes, J., Fisher, M. C., Mfinanga, S., Kivuyo, S., Rugemalila, J., ... \& Harrison, T. S. (2019). Dynamic ploidy changes drive fluconazole resistance in human cryptococcal meningitis. The Journal of clinical investigation, 129(3), 999-1014.

Suliman, S., Van Vuuren, S. F., Viljoen, A. M. (2010). Validating the in vitro antimicrobial activity of Artemisia afra in polyherbal combinations to treat respiratory infections. South African Journal of Botany, 76(4), 655-661. DOI: 10.1016/j.sajb.2010.07.003

Sykes, J. E., Hodge, G., Singapuri, A., Yang, M. L., Gelli, A., \& Thompson, G. R. (2017). In vivo development of fluconazole resistance in serial Cryptococcus gattii isolates from a cat. Medical mycology, 55(4), 396-401.

T. A. Mokoka, L. J. McGaw \& J. N. Eloff (2010) Antifungal efficacy of ten selected South African plant species against Cryptococcusneoformans, Pharmaceutical Biology, 48:4, 397-404, DOI: 10.3109/13880200903150393

Tamokou, J. D. D., Kuiate, J. R., Tene, M., Nwemeguela, T. J. K., Tane, P. (2011). The antimicrobial activities of extract and compounds isolated from Brillantaisia lamium. Iranian journal of medical sciences, 36(1), 24.

Temfack, E., Boyer-Chammard, T., Lawrence, D., Delliere, S., Loyse, A., Lanternier, F., Alanio, A., \& Lortholary, O. (2019). New Insights Into Cryptococcus Spp. Biology and Cryptococcal Meningitis. Current neurology and neuroscience reports, 19(10), 81.

Thirach, S., Tragoolpua, K., Punjaisee, S., Khamwan, C., Jatisatienr, C., \& Kunyanone, N. (2003). Antifungal activity of some medicinal plant extracts against Candida albicans and Cryptococcus neoformans. Acta horticulturae, 597, 217-221.

Valente, J., Zuzarte, M., Gonçalves, M. J., Lopes, M. C., Cavaleiro, C., Salgueiro, L., \& Cruz, M. T. (2013). Antifungal, antioxidant and anti-inflammatory activities of Oenanthe crocata L. essential oil. Food and chemical toxicology, 62, 349-354.

Valli, S., \& Shankar, S. G. (2013). Terminalia bellerica-a promising challenge to cryptococcosis. International Journal of Pharmaceutical Research and BioScience, 2(5), 154-169.

Van Duin, D., Casadevall, A., \& Nosanchuk, J. D. (2002). Melanization of Cryptococcus neoformans and Histoplasma capsulatum reduces their susceptibilities to amphotericin B and caspofungin. Antimicrobial agents and chemotherapy, 46(11), 3394-3400. 
Research, Society and Development, v. 10, n. 2, e57810212819, 2021

(CC BY 4.0) | ISSN 2525-3409 | DOI: http://dx.doi.org/10.33448/rsd-v10i2.12819

Vanden Berg, F., Kubiak, R., Benjey, W. G., Majewski, M. S., Yates, S. R., Reeves, G. L., ... \& Van der Linden, A. M. A. (1999). Emission of pesticides into the air. In Fate of Pesticides in the Atmosphere: Implications for Environmental Risk Assessment (pp. 195-218). Springer, Dordrecht.

Villis, P., de Macedo, A. T., Furtado, H. L., Fontenelle, P. H., Gonçalves, I. S., Mendes, T. L., ... \& Santos, J. R. (2021). A Study of the Disruptive Effect of the Acetate Fraction of Punica granatum Extract on Cryptococcus Biofilms. Frontiers in Microbiology, 11, 3533.

Wang, S., Wang, Z., Zhang, Y., Wang, J., \& Guo, R. (2013). Pesticide residues in market foods in Shaanxi Province of China in 201 0. Food Chemistry, 138(23), 2016-2025.

Watkins, R. A., King, J. S., \& Johnston, S. A. (2017). Nutritional requirements and their importance for virulence of pathogenic Cryptococcus species. Microorganisms, 5(4), 65 .

White, N. J. (1998). Preventing antimalarial drug resistance through combinations. Drug resistance updates, 1(1), 3-9.

Willger, S. D., Puttikamonkul, S., Kim, K. H., Burritt, J. B., Grahl, N., Metzler, L. J., ... \& Cramer Jr, R. A. (2008). A sterol-regulatory element binding protein is required for cell polarity, hypoxia adaptation, azole drug resistance, and virulence in Aspergillus fumigatus. PLoS Pathog, 4(11), e1000200.

Wimley, W. C. (2010). Describing the mechanism of antimicrobial peptide action with the interfacial activity model. ACS chemical biology, 5(10), 905-917.

World Health Organization. (2018). Guidelines for the diagnosis, prevention, and management of cryptococcal disease in HIV-infected adults, adolescents and children, March 2018: supplement to the 2016 consolidated guidelines of the use of antiretroviral drugs for treating and prev enting HIV infection. World Health Organization.https://apps.who.int/iris/handle/10665/260399.

Yang, M. L., Uhrig, J., Vu, K., Singapuri, A., Dennis, M., Gelli, A., \& Thompson, G. R. (2016). Fluconazole susceptibility in Cryptococcus gattii is dependent on the ABC transporter Pdr11. Antimicrobial agents and chemotherapy, 60(3), 1202-1207.

York, T., Van Vuuren, S. F., De Wet, H. (2012). An antimicrobial evaluation of plants used for the treatment of respiratory infections in rural Maputaland, KwaZulu-Natal, South Africa. Journal of Ethnopharmacology, 144(1), 118-127.

Yu, C. H., Chen, Y., Desjardins, C. A., Tenor, J. L., Toffaletti, D. L., Giamberardino, C., ... \& Cuomo, C. A. (2020). Landscape of gene expression variation of natural isolates of Cryptococcus neoformans in response to biologically relevant stresses. Microbial genomics, 6(1).

Zaragoza, O. (2019). Basic principles of the virulence of Cryptococcus. Virulence, 10(1), 490-501.

Zhang, L.; et al (2002). Expression profiling of the response of Saccharomyces cerevisiae to 5 -fluorocytosine using a DNA microarray. International journal of antimicrobial agents, 20.6: 444-450. DOI: 10.1016/s0924-8579(02)00201-7

Zhao, Y., Lin, J., Fan, Y., \& Lin, X. (2019). Life Cycle of Cryptococcus neoformans. Annual review of microbiology, 73, 17-42. 